
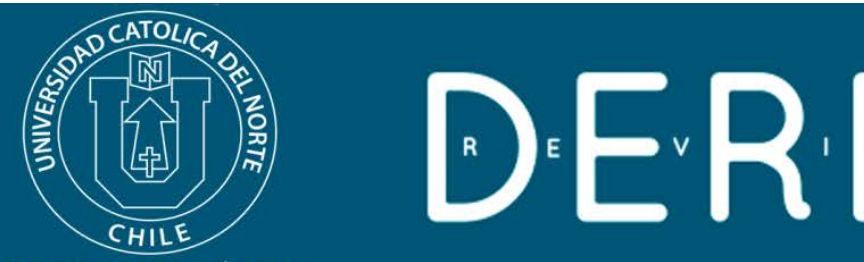

\title{
La nulidad como un medio de tutela precontractual en el Código Civil chileno: configuración, modalidad de ejercicio y eventual concurrencia con la resolución por incumplimiento
}

\section{Nullity as a means of pre-contractual protection in the chilean Civil}

Code: configuration, exercise mode and its eventual concurrence

with the resolution for breach of contract

Patricia Verónica López Díaz* (D) https://orcid.org/0000-0001-6716-0584

*Universidad de Valparaíso, Chile. Profesora. Doctora en Derecho, P. U. Católica de Valparaíso

@ patriciaveronica.lopezdiaz@gmail.com

(cc) BY

\section{Resumen:}

Se explora la posibilidad de concebir a la nulidad como medio de tutela precontractual en el Código Civil chileno, abordando su articulación y modalidad de ejercicio y examinando su eventual confluencia con la resolución por incumplimiento con el propósito de ilustrar al acreedor sobre la pertinencia y conveniencia de inclinarse por ella y determinar si ésta le dispensa una tutela simétrica a aquella propia de la resolución.

Palabras Clave: Nulidad del contrato; Desjudicialización; Opción del acreedor; Resolución.

\begin{abstract}
:
The possibility of conceiving the nullity as a pre-contractual remedy in Chilean Civil Code exploring its relationship with termination, analyzing it's articulation and exercise modality and explores its possible confluence with the resolution for non-compliance with the purpose of illustrating to the creditor the pertinence and convenience to choose it and determine if provides a symmetrical protection than the resolution.

Keywords: Nullity of the contracts; Desjudicialisation; Creditor's option; Resolution.
\end{abstract}




\section{Introducción}

Ciertamente la nulidad es uno de los tópicos que ha concitado incesantemente la atención de nuestra dogmática. Basta con examinar los tratados o manuales de Derecho Civil y las monografías y artículos específicos sobre la nulidad, desde el tratado de Rossel Saavedra(1926) hasta el libro del profesor Baraona González (2012), pues todos ellos analizan su naturaleza, causales, modalidad de ejercicio, efectos y su relación con la inexistencia y rescisión, trazando una delimitación entre éstas y aqueIla ${ }^{1}$ y evidenciando un seguimiento casi irrestricto de la doctrina francesa decimonónica, toda vez que, salvo algunas excepciones ${ }^{2}$, conciben a la nulidad como una sanción de ineficacia civil de carácter estricto que necesariamente debe ser declarada por sentencia judicial.

De allí que los esfuerzos realizados en el último tiempo se reconduzcan a determinar el alcance de algunas causales cuya formulación en el Código Civil es genérica, como acontece con la prevista en el artículo 1462 según la cual hay objeto ilícito en todo lo que contraviene el derecho público chileno (Concha Machuca, 2010) o confusa, cual es el caso de las hipótesis del artículo 1465 a propósito de la condonación del dolo futuro y la obtención dolosa de un finiquito contractual (Elorriaga De Bonis, 2009) o la noción de juegos de azar contenida en el artículo 1466 (Contardo González, 2015b). Y, de otro lado, se dirijan a analizar el ejercicio de la acción de nulidad por un tercero no contratante (Corral Talciani, 2007), la denominación nulidad absoluta y relativa (Baraona González, 2012, pp. 65-71), la pertinencia del efecto paralizador de la restituciones que consagra el artículo 1468 (Ríos Labbé, 2016, pp. 787-801) y la posibilidad que el juez declare de oficio la nulidad absoluta transcurridos diez años desde la celebración del acto o contrato (Concha Machuca, 2016).

Indudablemente el debate más arduo ha sido aquel que intenta contrastarla con la inexistencia y la rescisión. El primero es de larga data y se ha reconducido a determinar si la inexistencia tiene cabida en nuestro Código y, en tal evento, si es diversa a la nulidad absoluta ${ }^{3}$. Comenzó en el año 1926, oportunidad en que se estimó que la inexistencia constituía una sanción de ineficacia (Rossel Saavedra, 1926, pp. 39-81), aduciéndose que si bien no está regulada ni mencionada en el Código Civil existen diversos preceptos de los que ella podría desprenderse, indicándose además que la frase "la omisión de algún requisito o formalidad exigida para el valor de acto o contrato en consideración a su naturaleza" contenida el artículo 1682 sólo se refiere a los requisitos de existencia del acto y que el inciso final de dicho precepto sanciona a los actos irregulares de los incapaces absolutos con nulidad absoluta y no con inexistencia, dado que éstos pueden aparentar voluntad (Claro Solar, 1939, p.

\footnotetext{
${ }^{1}$ Fabres (1908, pp. 89), Rossel Saavedra (1926, p. 2), Alessandri Besa (1949), Pescio (1958, p. 199), Claro Solar (1939, pp. 580-651), Ducci Claro (1988, pp. 315-330), Rodríguez Grez (1995, pp. 124-126), Vial del Río (2003, pp. 247-290), Domínguez Águila (2012) y San Martín Neira (2015, pp. 769-770) y Concha Machuca, Ricardo (2015, pp. 31-49).

${ }^{2}$ Fabres (1908, p. 145-170), Baraona González (2012, pp. 50-63), Alcalde Silva (2010, p. 69), San Martín Neira (2015, pp. 769-770) y tratándose de la nulidad radical Rodríguez Grez (1995, p. 129-135).

${ }^{3}$ Una síntesis en Rodríguez Grez (1995, p. 68-79), Vial del Río (2003, pp. 237-241), San Martín Neira (2015, pp. 754-756, 762-768) y Ugarte Godoy (2016, pp. 823-840).
} 
$600)^{4}$. Paralelamente, se sostuvo la tesis contraria, argumentándose que el Código no la consagraba, que la referida frase comprendería los requisitos de existencia y validez del acto y que el inciso final de dicho artículo sanciona los actos de los incapaces absolutos, a pesar que falta la voluntad, porque la inexistencia no tiene cabida en nuestro Código. Esta corriente de opinión ha sumado en el último tiempo un argumento histórico que arrojaría que don Andrés Bello no habría contemplado la inexistencia, dado que ésta equivaldría a la nulidad absoluta, innovando aparentemente al establecer el saneamiento de la acción, pues en realidad correspondería a su plazo de extinción (San Martín Neira, 2015, pp. 760-762)5.

En lo que concierne a la rescisión, la discusión ha sido más tardía y se ha suscitado por la aparente y confusa sinonimia entre ésta y la nulidad relativa. Tal equiparación ha sido descartada por un sector de nuestra doctrina, atendiendo a diversos argumentos. De un lado, se ha sostenido que la rescisión parece ser más bien el efecto que la causa de la nulidad (Baraona González, 2008, p. 667). De otro, que la recisión no se agota en la nulidad relativa, sino que la nulidad es una de las causas de la rescisión, pero no la única (Alcalde Silva, 2010, pp. 68-71). Y, finalmente, que ellas se diferencian en cuanto a su fundamento, efectos y tipo de ineficacia (López Díaz, 2017, p. 437). Así, la nulidad encontraría su fundamento en algún vicio o defecto de los elementos esenciales del acto, en cambio la rescisión en un agravio jurídico-económico. La primera tendría un carácter principal y efecto invalidatorio, a diferencia de la segunda que sería subsidiaria y compatible con la subsistencia total o parcial del vínculo contractual y, en ocasiones, se traduciría en una compensación de la lesión inferida. Por otra parte, la nulidad sería un tipo de ineficacia estructural que exigiría se pruebe el vicio del que adolece el negocio, a diferencia de la rescisión, que constituiría una forma de ineficacia funcional en que debe acreditarse el perjuicio que el contrato ocasiona ${ }^{6}$.

Lo preocupante es que dicha sinonimia no sólo es errada, sino peligrosa, pues ha inducido a confusión tratándose de la naturaleza jurídica de instituciones como la lesión enorme y la acción redhibitoria, sosteniéndose que aquella es un vicio del consentimiento (Ducci Claro, 1988, p. 244-245) ${ }^{7}$ y ésta última es de naturaleza anulatoria $^{8}$, por el sólo hecho que el legislador utiliza la voz rescisión en los artículos 1234, 1348, 1351-1353,1853-1854, 1888-1898 y 1900 a propósito de la lesión enorme, y en los artículos 1857 y 1860 tratándose de la acción redhibitoria. Esta interpretación literal debe ser superada, pues crea, al menos, dos distorsiones en el régimen de la nulidad. De un lado, considera como vicio del consentimiento a la lesión enorme en circunstancias que de los casos regulados en nuestro Código Civil y del tenor del artícu-

\footnotetext{
${ }^{4}$ Adhiriendo a este planteamiento Vial del Río (2003, pp. 241-245), Rodríguez Grez (1995, p. 31), distinguiendo entre inexistencia propia e impropia (189-190) y Ugarte Godoy (2016, p. 817).

${ }^{5}$ Su opinión complementa la de Domínguez Águila (2012, p. 179), que la justifica en caso de inobservancia de solemnidades para negar el saneamiento o la prescripción adquisitiva.

${ }^{6}$ Martín Pérez (1995, pp. 190-192, 208-210), Díez-Picazo (2007, p. 613) y Alberruche Díaz-Flores (2010, pp. 158-159).

${ }^{7}$ Específicamente un error sustancial.

${ }^{8}$ Guzmán Brito (2007, p. 99-101) y Baraona González (2008, pp. 665, 669).
} 
lo 1451 se infiere precisamente lo contrario ${ }^{9}$. Y, por otro, extiende esta naturaleza a una acción que no podría tenerla, ya que su supuesto de hecho, finalidad y efectos son diversos, al igual que la diligencia que se exige al comprador en uno y otro caso. De allí que sea más correcto concebirla como una acción rescisoria en sentido técnico estricto (López Díaz, 2017, pp. 443-453).

Parecería inoficioso, entonces, volver sobre la nulidad, pues, de lo referido hasta acá, aparece como un tópico prácticamente agotado entre nosotros. A menos que, como creemos, existan aristas que no han sido suficientemente exploradas y que determinan la necesidad de reformular algunas premisas, como acontece específicamente tratándose de su naturaleza jurídica y modalidad de ejercicio. Y es que, si bien el análisis efectuado por nuestra civilística es acucioso desde la perspectiva de la teoría clásica y moderna de la nulidad, no se ha abordado desde aquella más reciente para acuñar un enfoque protector de ella y concebirla, además, como una medida de tutela extrajudicial ${ }^{10}$.

Este ha sido precisamente el modelo propugnado por el movimiento de modernización del derecho de obligaciones y contratos a propósito de la nulidad relativa, como se advierte en los artículos 4:112 de los Principios europeos de derecho de los contratos (PECL), II.- 7:209 del Draft Common Frame of Reference (DCFR), 3.2.12 de los Principios de UNIDROIT sobre Contratos Comerciales Internacionales (PICC), 1305 de la Propuesta española de Modernización de Derecho de Obligaciones y Contratos $(P M E)$ y 527-13 de la Propuesta de Código Civil relativa a los Libros Quinto y Sexto elaborada por la Asociación de profesores de Derecho Civil español de 2016 (PA$P D C)^{11}$ que no sólo evidencian que podríamos haber leído erradamente la nulidad relativa en todos estos años, sino que, a la vez, parece más acertado que el que tradicionalmente ha sugerido nuestra doctrina mayoritaria y prevalente. Una dirección similar ha seguido el artículo 1178 Code, introducido por la Ordenanza N ${ }^{\circ} 2016-131$ de 10 de febrero de 2016, en lo que concierne a la modalidad extrajudicial. Miradas las cosas desde esta perspectiva, debería repensarse si la nulidad, sea relativa o absoluta, es, efectivamente, una sanción o es, en realidad, un medio de tutela y si debe defenderse a ultranza su carácter judicial o, por el contrario, admitirse su desjudicialización.

De otro lado, y proyectando su análisis a la tutela que ésta otorga al acreedor, cabe preguntarse en qué casos ella puede confluir con la resolución por incumplimiento, toda vez que tal examen nos permitirá constatar si ésta, en realidad se justifica, o basta con la resolución contractual, que la absorbería. La interrogante es relevante, particularmente porque en la última década la dogmática comparada, y la

\footnotetext{
${ }^{9}$ Salvo Ducci Claro (1988, p. 244-245). Es precisamente esta diferencia la que impide asimilar la lesión enorme a la noción de excesiva desproporción o ventaja injusta acuñada por el movimiento de modernización del derecho de obligaciones y contratos. Sobre este tópico véase Ginés Castellet (2016).

${ }^{10}$ Excepcionalmente se ha propugnado el ejercicio extrajudicial de la nulidad absoluta (Fabres, 1908, p. 145-170), Baraona González (2012, p. 50-63), Alcalde Silva (2010, p. 69) y San Martín Neira (2015, pp. 769-770) y de la nulidad relativa, sugiriéndose que se trata de un medio de tutela, (López Díaz, pp. 473-477).

${ }^{11}$ Fenómeno que no se advierte en los Principios de Derecho Latinoamericano de Contratos (PLDC), a diferencia de lo que acontecía en su primera versión. Véase Severin Fuster (2017, pp. 1493-1494)-
} 
nacional más reciente ${ }^{12}$, se ha inclinado por proyectar las anomalías o disconformidades acaecidas en la fase precontractual a la contractual, desplazamiento que podría inducir a pensar que la primera no se justifica.

Nuestro objetivo, entonces, es explorar si es posible perfilar a la nulidad como un medio de tutela precontractual, que, en cuanto tal se articula con otros propios de dicha fase y que, eventualmente, puede confluir con la resolución. Para alcanzarlo dividiremos este artículo en tres secciones. La primera abordará la discusión relativa a su naturaleza jurídica, distinguiendo la tesis tradicional que la entiende como sanción y la moderna que la concibe como un medio de tutela, inclinándonos fundadamente por ésta última tratándose de la nulidad relativa y desechándola respecto de la nulidad absoluta:

1. Seguidamente, se analizará la conveniencia de adoptar tal enfoque y cómo éste incide en la tutela del acreedor, precisando que permite prescindir de su declaración judicial y que, además, justifica su eventual confluencia con la resolución por incumplimiento

2. Finalmente, se explorarán los supuestos en que puede advertirse tal convergencia y se ensayará un cotejo del alcance de la tutela que ambas dispensan al acreedor

3. Examinados tales tópicos, se formularán las conclusiones.

\section{La naturaleza jurídica de la nulidad: entre la ineficacia civil y la protección del contratante perjudicado}

Una revisión histórica de la nulidad evidencia que la determinación de su naturaleza jurídica no ha sido un tópico particularmente pacífico. llustrativa resulta a estos efectos la discusión que se suscitó en la dogmática francesa, pues entre los siglos XIX a XXI transitó por diferentes etapas, acuñando cada cual una noción particular de ella que, repercutió en su ratio essendi.

En efecto, en un primer momento, la pretendida teoría clásica formulada por Demolombe (1876, pp. 24-31) en el siglo XIX, propuso una concepción descriptiva y estática de nulidad, entendiendo que es un estado natural del acto, bajo la premisa que el acto jurídico es un organismo y, en cuanto tal, está integrado por órganos esenciales y otros accesorios o susceptibles de estar viciados, representados, respectivamente, por las condiciones de existencia y validez. La ausencia de alguno de ellos afecta con mayor o menor intensidad su vida: en el primer caso determinará su muerte (inexistencia o nulidad absoluta) en tanto, en el segundo, lo dejará a medio camino entre la vida y la muerte (será anulable). Por consiguiente, la nulidad aparece como una patología del acto que constituye una consecuencia lógica de un vicio que existe desde su celebración y que, por lo mismo, el juez sólo se limita a constatar ${ }^{13}$.

\footnotetext{
${ }^{12}$ De la Maza Gazmuri (2010, p. 273-274), García Rubio y Otero Crespo (2010, p. 56), Morales Moreno (2010, pp. 89-91), Díez-Picazo y Gullón Ballesteros (2015, pp. 29-30) y Prado López (2016, pp. 442-451). ${ }^{13}$ La Pradelle (1967, pp. 27-42), Couturier (1972, p. 3-6), Cumyn (2002, pp. 15-25) y Thibierge (2010, pp. 329-332).
} 
Si bien se ha discutido en la dogmática gala que esta teoría realmente haya sido formulada por Demolombe (1860, pp. 384-390) ${ }^{14}$, entender que ella realmente existió permitió dar paso a la denominada teoría moderna, propiciada por Japiot (1909, pp. 43-44, 284, 710) que sostuvo que era equívoco concebirla como un estado del acto y propuso una noción sustancial y procesalista de la nulidad que entiende que ella es un derecho de crítica dirigido contra las consecuencias del acto, que sanciona la violación de una norma legal y se concede a quienes tienen el derecho a invocarla ${ }^{15}$. El elemento determinante de la nulidad no será la gravedad del vicio, sino la norma transgredida, superándose la distinción entre nulidad absoluta y relativa. Sin embargo, esta reducción de la nulidad a un derecho subjetivo impide distinguirla de la acción de nulidad, no explica cómo se producen sus efectos, desconoce la existencia del vicio del que adolece el acto y no admite que la nulidad y el derecho de crítica tienen una existencia separada ${ }^{16}$ (Bandrac, 1986).

A partir de tales críticas se reformuló el fundamento de la nulidad y se transitó a un enfoque objetivo (Bandrac, 1986, pp. 157, 159-160), acuñándose una noción sustancial, según la cual ésta es una sanción que acarrea la desaparición de los efectos jurídicos del acto en la medida de la violación de la ley ${ }^{17}$. El derecho de crítica sería, entonces, uno de los medios para aplicar la sanción de la nulidad que no debe reducirse a un concepto procesal: el presupuesto de aquella es el vicio originario del que adolece y su sustancia la privación de los efectos que el acto acarrea (Thibierge, 2010, pp. 343-344). La nulidad no sancionaría, entonces al acto mismo ni a las partes que lo han celebrado, toda vez que, si bien fue concebida como una noción subjetiva en el derecho romano ${ }^{18}$, su origen histórico no es trasladable al derecho positivo. Castigaría, la violación de la ley, persiguiendo el restablecimiento de la legalidad trasgredida mediante la supresión de la situación jurídica ilícita creada por la celebración del contrato. Se trataría de una noción doblemente objetiva; en cuanto a su origen, esto es, la violación del derecho objetivo, y al resultado, cual es, la restauración del imperio de la ley (Thibierge, 2010, pp. 338-339, 352 y 487), aproximándose a lo que Roubier (2005, pp. 73-75) denominó situación jurídica objetiva de reacción, ya que está fundada en la infracción del deber de observancia de las condiciones de validez del acto, al margen de cualquier derecho preexistente, debiendo el juez ya no constatarla, sino de declararla.

\footnotetext{
${ }^{14}$ Pues una detenida revisión de la obra de Demolombe revela que en realidad este autor no formuló ninguna teoría sino que propuso una fusión del régimen de nulidades y exclusivamente con ocasión del contrato de matrimonio se apartó de ella y aludió al acto nulo (inexistente) como muerto no nacido y al anulable como nacido enfermo, retomando la idea que la nulidad (inexistencia) operaba de pleno derecho. Precisamente por este motivo Posez (2011) sostiene que la teoría clásica verdaderamente fue formulada por Japiot (1909, p. 44-46), quien le atribuyó a Demolombe una teoría orgánica fundada en la gravedad del vicio del acto para proponer su propia teoría en el Siglo XX que fue conocida como moderna. A tal conclusión puede arribarse revisando el trabajo anteriormente citado.

${ }^{15}$ La Pradelle (1967, pp. 70-74, 116-118), Couturier (1972, pp. 112-114) y Thibierge (2010, pp. 335-342).

${ }^{16}$ Un detenido análisis y visión panorámica de los efectos derivados de esta equiparación en Thibierge (2010, pp. 337-342).

${ }^{17}$ Ghestin (1980, pp. 626, 643-644), Starck (1986, pp. 293-319), Voirin y Gobeaux (2011, pp. 441-447).

${ }^{18}$ Una síntesis de la noción subjetiva en Thibierge (2010, pp. 345-350).
} 
Finalmente, en el último estadio de la dogmática francesa el interés ya no se focaliza en la noción ni en la naturaleza jurídica de la nulidad, sino en las clasificaciones que ella admite, abandonándose la formulación de teorías destinadas a abogar por alguna de las ya enunciadas o por una diversa ${ }^{19}$. Tales clasificaciones se han realizado a partir de dos criterios: el objeto que persigue la nulidad y el objeto afectado por el vicio. El primer criterio es acuñado por Lichbacher (2007), quien propone la clasificación que distingue entre nulidades de restauración, evicción y alerta. El segundo es propuesto por Posez (2011, pp. 647-675) que sugiere diferenciar la nulidad absoluta y relativa, atendiendo al elemento interno o externo del contrato viciado.

Con todo, y más allá de las diferentes teorías y clasificaciones a las que hemos aludido, quien demanda la nulidad, como acertadamente lo sugiere Thibierge (2010, p. 358), siempre persigue la satisfacción de su interés, advirtiéndose una diferencia entre la finalidad objetiva de la nulidad y el propósito perseguido por el demandante. Así la autora, después de examinar la noción de nulidad en las diferentes épocas de la dogmática francesa, sostiene que se trata de una sanción jurídica sustancial y objetiva que consiste en la supresión de los efectos jurídicos del acto (aspecto negativo) en la medida necesaria para el restablecimiento de la legalidad transgredida durante su conclusión (aspecto positivo) ${ }^{20}$, plasmando elementos de la teoría clásica (el estado del acto viciado) y de la teoría moderna (la legalidad violada) y diferenciándola del derecho de crítica (Thibierge, 2010, pp. 358, 370-371).

Pues bien, si atendemos a esta finalidad satisfactiva, nos situamos ante una noción próxima a la de medio de tutela, sea que lo entendamos en un sentido amplio propio del common law o en la acepción restringida acuñada en la dogmática española. En efecto, según la primera, se trata de los cursos de acción de que dispone el acreedor para enfrentar tal insatisfacción (Campbell, 2005, p. 3); en cambio, la segun$\mathrm{da}$, lo circunscribe a las pretensiones y derechos potestativos del acreedor destinados a tal finalidad, encontrándose en este último grupo la nulidad, dado que, al igual que la resolución, lo faculta para modificar, a través de su voluntad, una determinada situación jurídica (Morales Moreno, 2011, p. 402).

Lo cierto es que, no obstante, la elaborada reflexión de los juristas franceses en torno a la naturaleza jurídica de la nulidad, no se planteó la alternativa de concebirla como un medio de tutela del contratante perjudicado. Claro está que a través de la noción de derecho a crítica se aproximaron, pero desde una perspectiva más bien procesalista y no tuitiva o protectora. De hecho, a pesar del influjo que ha tenido el movimiento de modernización del derecho de obligaciones y contratos en los ordenamientos jurídicos europeos, incluyendo al francés, de lo que da cuenta la Ordenanza N²016-131 de 10 de febrero de 2016 que modificó el Code en esta materia, aún se utiliza la denominación sanction que jurídicamente viene a significar "medida de reacción por una violación de la legalidad" ${ }^{21}$.

\footnotetext{
${ }^{19}$ Para una visión panorámica de las ideas sobre las que ha teorizado la dogmática francesa a propósito de la nulidad véase Drogoul, F. (1902) y Mekki (2017, pp. 115-117).

${ }^{20}$ Esta doble dimensión ya había sido destacada por Couturier (1972, pp. 112-113).

${ }^{21}$ Véase Guinchard y Debard (2016, p. 988) Así lo revela el enunciado de la Sección 4 del Título III “De las fuentes de las obligaciones" en que se encuentra la nulidad.
} 
Nuestra civilística, por su parte, si bien en ocasiones ha consignado la evolución de la doctrina francesa en lo que concierne a la naturaleza jurídica de la nulidad $^{22}$, sólo se ha detenido en aquella que postula que ésta es una sanción o reacción, acuñándola, muy probablemente, porque fue la última en instalarse en la dogmática gala. Por tal motivo, indagaremos si las premisas sobre las cuales se ha erigido esta teoría entre nosotros son tan concluyentes como tradicionalmente se ha pensado o, por el contrario, un análisis más detenido, nos conduce en una dirección opuesta.

Y es que resulta indiscutible, como lo ha sostenido Roubier (2005), que las instituciones jurídicas apuntan al hombre, "sancionándolo o protegiéndolo"(p. 302), frase que, en lo que aquí interesa, abre tres complejas interrogantes que intentaremos dilucidar en las líneas que siguen, recurriendo a diversos argumentos dogmáticos que permitan determinar la naturaleza jurídica de la nulidad:

1. ¿Existe alguna vinculación causal entre la protección y la sanción?

2. En el evento que la respuesta fuera afirmativa, ¿qué es primero: la sanción del deudor infractor (efecto negativo) o la protección del perjudicado (efecto positivo) y, finalmente,

3. ¿Sanción y protección constituyen dos perspectivas distintas, pero complementarias para apreciar un mismo fenómeno o son excluyentes?.

\subsection{La nulidad relativa es un medio de tutela precontractual: refutación de la tesis que le atribuye una naturaleza sancionatoria}

Una revisión de la literatura jurídica nacional permite constatar que, con excepción de Alessandri Besa (2008, p. 20) ${ }^{23}$, desde antiguo se ha concebido a la nulidad relativa como una sanción de ineficacia civil, siguiendo muy de cerca a la francesa. Con esta denominación pretenden significar que ella constituye una represión o castigo del acto viciado que los contratantes han decidido celebrar, situándose el énfasis en la privación de sus efectos, a partir probablemente de la idea que es irrelevante la causa de tal privación. La naturaleza jurídica de la nulidad quedaría determinada, entonces, por la consecuencia jurídica adversa que acarrea (efecto) y no por la finalidad que se persigue con aquella, cual es la tutela de el o los contratantes perjudicados (causa) (Alessandri Besa, 2008, p. 19).

No ha ocurrido lo mismo en la doctrina comparada, pues en la última década ha adoptado un nuevo enfoque que ya se advertía en los postulados de Giorgi (1913), que consignaba que la nulidad es el "medio jurídico concedido al contratante que se obliga sin validez o fue lesionado por el contrato, para librarse de los efectos perjudiciales de la obligación asumida, obteniendo la anulación o rescisión que desea" (p. 217-218). Y es que, si bien históricamente sólo se vinculó la nulidad relativa con defectos estructurales del contrato, imprimiéndole un carácter sancionador, ha comenzado a concebirse como una medida protectora, esto es, un instrumento al

\footnotetext{
${ }^{22}$ Rossel Saavedra (1926, pp. 4-30), Baraona González (2012, pp. 25-29) y San Martín Neira (2015, pp. 746-754, 759-762).

${ }^{23}$ Quien admite que la nulidad relativa es una medida de protección.
} 
servicio de la función tuitiva (Jerez Delgado, 2011, p. 51-53, 65, 72), prescindiendo de tales defectos y reformulándose la teoría clásica de la nulidad ${ }^{24}$.

Ha sido la dogmática española la que ha acuñado este enfoque respecto de la nulidad relativa, a partir de la idea de derecho potestativo y, más recientemente, de autotutela. Así, De Cossio y Corral (1977, p. 184) califica la solicitud para que se declare la ineficacia de un contrato como un derecho facultativo y Díez-Picazo (2007, p. 592) como un derecho potestativo, facultad jurídica o poder jurídico, cobrando relevancia la ya examinada acepción estricta de medio de tutela, según la cual éste comprende el conjunto pretensiones y derechos potestativos del acreedor destinados a satisfacer su interés (Morales Moreno, 2011, p. 402). Es precisamente a partir de tales reflexiones que Jerez Delgado $(2011$, p. 72$)$ sugiere concebir la nulidad relativa como una forma autotutela, pues ella implica la defensa de un interés particular que el legislador considera digno de protección, en que el legitimado puede ejercitar su derecho con independencia del otro contratante y sin necesidad de acudir a tribunales, perfilándola como extrajudicial.

A pesar que estos autores no formulan detenidamente premisas que expliquen y justifiquen concebir a la nulidad como un medio de tutela del acreedor, estimamos que es posible atribuirle este carácter, en atención, al menos, a dos argumentos: (1) La nulidad otorga al contratante perjudicado la facultad de desvincularse del contrato viciado y (2) La privación de efectos del acto es una consecuencia de la tutela anulatoria.

La perspectiva que sugerimos, como se advertirá en las líneas que siguen, presenta dos ventajas. De un lado, es inclusiva, pues contempla la aniquilación del acto como un efecto negativo, pero cuya causa se encuentra en la tutela que se otorga al contratante perjudicado. De otro, se aviene con el cambio de paradigma que propugna el movimiento de modernización del derecho de obligaciones y contratos, toda vez que, al igual que aquél, supera la idea de sanción focalizando su atención en la protección del contratante perjudicado (Vidal Olivares, 2017) ${ }^{25}$, perspectiva que resulta más conveniente tratándose de la nulidad relativa, dado que, como se analizará en el último apartado de esta investigación, éste podrá decidir si inclinarse por este medio de tutela o por la resolución, en el evento que ambas converjan.

\subsubsection{La nulidad otorga al contratante perjudicado la facultad de desvincularse del contrato viciado}

Como es bien sabido, el legislador establece la procedencia de la nulidad en atención a diversas causales, según ésta sea absoluta o relativa. Tratándose de la primera contempla aquellas que refiere el artículo 1682 del Código Civil, esto es, el objeto ilícito, la causa ilícita, la falta de las solemnidades requeridas para el valor del acto y los actos irregulares de los absolutamente incapaces, agregándose, si se des-

\footnotetext{
${ }^{24}$ Para un completo análisis Thibierge (2010, pp. 325-373).

${ }^{25}$ Superando la idea de sanción que subyace en Fueyo Laneri (2004, p. 256). Este cambio de paradigma se sustenta en la premisa según la cual la noción de incumplimiento supone la falta de satisfacción del interés del acreedor garantizado por el contrato (Morales Moreno, 2006, pp. 30-32).
} 
carta que la inexistencia tiene cabida en el Código, la ausencia de voluntad, causa y objeto, el error esencial y la falta de solemnidades exigidas para la existencia del acto o contrato. En cambio, a partir de la frase "cualquiera otra especie de vicio produce nulidad relativa" contenida en el inciso final de dicho precepto, se ha entendido que son causales de nulidad relativa, los vicios del consentimiento, la omisión de formalidades habilitantes, los actos irregulares de los relativamente incapaces y, erróneamente ${ }^{26}$, la lesión enorme en la compraventa y permuta de bienes inmuebles, en la partición de bienes y en la aceptación de una asignación hereditaria ${ }^{27}$.

La pregunta que surge, entonces, es qué persigue el legislador al tipificar estas causales: ¿Proteger o sancionar? Y la respuesta es que pretende tutelar a quien ha quedado vinculado por un contrato viciado a través de su aniquilación, debiendo desestimarse, a nuestro juicio, la idea según la cual "que la ley declare nulo el acto y sin valor" equivale a que ella la "sanciona" (Baraona González. 2012, pp. 44, 46). Esta expresión sólo quiere significar, como acontece con los otros medios de tutela, que la ley la establece para que el perjudicado recurra a ella, pues de lo contrario no podría impetrar tal protección. Lo que ocurre es que el Código prevé y tipifica sus causales, pero de ello no se sigue que le confiera una naturaleza sancionatoria.

Por otra parte, como han precisado Irti $(1987$, p. 542) y Delgado Echeverría (2007, pp. 89-91, 118-119, 125) ${ }^{28}$, a partir de las premisas asentadas por Hart (1977, p. 42-61), Atienza Rodríguez y Ruíz Manero (2003, pp. 731-733), la sanción es una consecuencia de la infracción de una norma de mandato, a diferencia de la nulidad, que deriva de la inobservancia de reglas que confieren poderes. Es precisamente por este motivo que las últimas no pueden ser infringidas $y$, por ende, no se verifica sanción alguna. En otras palabras, la nulidad no hace más que evidenciar la ausencia de presupuestos para que el acto celebrado produzca efectos, pero no denota el incumplimiento de una obligación o prohibición, no obstante lo cual el ordenamiento jurídico reacciona ante aquella tutelando al contratante perjudicado, facultándolo para desvincularse del contrato.

La finalidad protectora de la nulidad relativa fluye con claridad si se considera, como hemos asentado al inicio de este artículo, que un medio de tutela es todo curso de acción de que dispone el acreedor para procurar la satisfacción de su interés, así como aquellas pretensiones y derechos potestativos del acreedor destinadas a tal finalidad $^{29}$. Su fundamento radicaría, como sugiere Morales Moreno (2011, p. 409), en la necesidad de tutelar a quien ha celebrado un contrato no querido, (porque ha existido intimidación que vicia su consentimiento), o con un contenido no querido (si ha incurrido en un error con trascendencia anulatoria o ha sido inducido a celebrar dolosamente un acto o contrato, hipótesis a las que pueden agregarse la contratación con un incapaz relativo que no ha realizado tal inducción ${ }^{30}$ o la ausencia de formali-

\footnotetext{
${ }^{26}$ Pues en este caso el legislador empleó la voz "rescisión" en sentido estricto y no como sinónimo de nulidad. Véase López Díaz (2017b, pp. 685-699).

${ }^{27}$ Por todos Alesssandri Besa (2008b, pp. 72-83).

${ }^{28}$ En nuestra doctrina San Martín Neira (2015, p. 763, n. 109) y Concha Machuca (2015).

${ }^{29}$ Campbell $(2005$, p. 3) y Morales Moreno (2011, p.402), respectivamente.

${ }^{30}$ Pues, si la ha realizado, el artículo 1685 del Código Civil lo priva de la acción de nulidad, al igual que a sus herederos y cesionarios.
} 
dades habilitantes, dado que inciden en el contenido contractual, configurando causales de nulidad relativa no deseadas por dicho contratante). $\mathrm{O}$, al menos tratándose de los vicios del consentimiento, en la infracción del deber de lealtad (en el caso de la intimidación) y en la vulneración de éste y del deber de información (error o dolo) (López Díaz, 2017c, pp. 470-472).

La naturaleza tuitiva de la nulidad que sugerimos radica su foco de atención en el contratante perjudicado, categoría que comprende al acreedor y al deudor, como acontecerá si este último es compelido a cumplir una prestación nacida de una obligación en que su consentimiento está viciado o en la que se han omitido las formalidades habilitantes o solemnidades pertinentes. De otro lado, el artículo 1684 del Código Civil faculta a alegar la nulidad relativa "al contratante en cuyo beneficio la ley la ha establecido, sus herederos o cesionarios", fenómeno que no se advierte tratándose de la nulidad absoluta, toda vez que el artículo 1683 no radica exclusivamente la legitimidad para impetrarla en los contratantes ni en quienes ocupen su misma posición jurídica. Volveremos sobre este punto.

Resulta claro que el contratante en cuyo beneficio la ley ha establecido la nulidad relativa es el que ha contratado o ejecutado un acto con error, fuerza o dolo y los incapaces relativos, salvo que hayan inducido dolosamente al acto o contrato. Y que, como los herederos suceden al causante en todos sus derechos y obligaciones trasmisibles, la legitimación también debe extenderse a ellos. La pregunta que surge, entonces, es por qué motivo ella comprende a sus cesionarios y la respuesta fluye precisamente de la finalidad protectora propia de la nulidad relativa, toda vez que vienen a reemplazar al contratante perjudicado, pues éste le ha transferido exclusivamente a ellos, por acto entre vivos, su derecho a alegar la nulidad o bien todos los derechos o acciones derivados del acto nulo, entre los que se comprende el derecho a impetrarla.

De lo dicho hasta acá, ha quedado claro que el análisis de la nulidad relativa debe abordarse desde una perspectiva tuitiva y no sancionatoria. El énfasis debe situarse, entonces, en la protección que ésta dispensa y no en la forma en que se alcanza o, si se quiere, en el efecto derivado de aquella, porque, como veremos a continuación, ésta es sólo una consecuencia de la primera, de modo que, cualquiera sea el supuesto en que nos encontremos, no puede determinar su naturaleza jurídica.

\subsubsection{La privación de efectos del acto es una consecuencia derivada de la tutela anulatoria}

Como ha quedado asentado más arriba, la privación de efectos que la nulidad acarrea obedece a su finalidad tuitiva. Dicho de otra manera: se establece una consecuencia adversa, porque se quiere proteger a quien ha celebrado un contrato viciado, afirmación que supone, de un lado, determinar el motivo por el cual la protección antecede a la sanción y, de otro, configurar a la nulidad como un medio de tutela. La segunda de estas cuestiones ya ha quedado establecida. La primera, en cambio, ratifica la segunda y encuentra respuesta en la lógica de la relación causa-efecto, pues la tutela es, indiscutiblemente, la causa de la privación de efectos del acto, que, por lo mismo, deviene en su efecto o consecuencia. 
Pues bien, jurídicamente la expresión sanción evoca la idea de castigo o represión, en tanto, tutela equivale a protección. Por consiguiente, y como ya lo hemos advertido, la sanción focaliza su atención en el infractor, desconociendo la causa que justifica la aniquilación del acto o contrato y tutela, en cambio, razonablemente la incorpora, desplazando la mirada al perjudicado y la necesidad de ampararlo jurídicamente, restableciendo así la ordenación cronológica que la expresión sanción ha socavado. Miradas las cosas desde esta perspectiva, es posible advertir que ambas nociones que representan, respectivamente, el enfoque clásico y reciente de la nulidad, no son excluyentes, sino sucesivas y comprensivas de un mismo fenómeno: la protección del contratante perjudicado.

\subsection{Dificultades para extender esta calificación a la nulidad absoluta}

Asentada la naturaleza tuitiva de la nulidad relativa surge la siguiente interrogante que nos remonta a la pertinencia de la distinción entre nulidad absoluta y relativa: ¿es posible concebir a la nulidad absoluta como un medio de tutela del contratante perjudicado? La pregunta adquiere relevancia no sólo desde lo que podríamos denominar la perspectiva clásica de la nulidad absoluta en nuestra dogmática sino también desde la más contemporánea, puesto que, como veremos, a un escollo tradicional, cual es la legitimidad para impetrarla, se agrega uno reciente, representado por su operatividad ipso iure o de pleno derecho.

\subsubsection{La legitimación para impetrarla no se agota en los contratantes}

Como es bien sabido, el artículo 1683 del Código Civil dispone que la nulidad absoluta no sólo "puede y debe ser declarada por el juez, aún sin petición de parte, cuando aparece de manifiesto en el acto o contrato", sino también alegarse "por todo el que tenga interés en ello, excepto el que ha ejecutado el acto o contrato sabiendo o debiendo saber el vicio que lo invalidaba", y solicitarse por "el ministerio público en el interés de la moral o de la ley".

Esta amplia legitimación, que contrasta con aquella contemplada para la nulidad relativa en el artículo 1684 que sólo faculta para reclamarla aquellos en cuyo beneficio la han establecido las leyes, sus herederos o cesionarios, se ha explicado mayoritaria y tradicionalmente ${ }^{31}$ en atención al distinto interés que tutelan ambas nulidades. El interés protegido por el legislador en la absoluta sería el general, lo que justificaría que ésta fuera procedente por infracción de ley, orden público y buenas costumbres; en tanto, en la relativa sería el particular, premisa que explicaría que ella

\footnotetext{
31 Por todos Alessandri Besa (2008, p. 100-101). En contra Rossel Saavedra (1926, pp 29-35) y Baraona González (2012, pp. 47-48), que postula que la nulidad siempre sirve el interés general, aun cuando su motivación directa sea el interés de los particulares. En lo que respecta al origen de esta distinción entre interés general y particular Rossel Saavedra (1926, pp. 12-29) y San Martín Neira (2015, pp. 746754).
} 
se aplique cuando estuviera involucrado el interés de los sujetos referidos en el artículo 1684 del Código Civil.

Como señala Alessandri, siguiendo la moderna teoría francesa de las nulidades $^{32}$, es "un interés social" el que la ley tiene en mira al establecer la nulidad absoluta respecto de actos y contratos que afecten el orden público más que el interés simplemente particular y patrimonial de las personas que ejecutan o celebran el acto o contrato. El legislador consideraría de tal gravedad las infracciones a ese orden público que autoriza a cualquier interesado a solicitarla, atendiendo no al perjuicio pecuniario de quienes se encuentran legitimados para impetrarla, sino a un "alto fin moral" y de "bien público" que repudian lo ilícito, entendiendo por tal todo aquello que contraviene la ley directamente (como la omisión de requisitos fundamentales de un acto jurídico o la celebración de actos prohibidos por ley) o indirectamente (al contravenir la moral, las buenas costumbres o el orden público, que al estar tutelados por la ley se traducen en una contravención a ella) (Alessandri Besa, 2008, p. 131).

Por consiguiente, de conformidad al artículo 1683, podría ocurrir que la nulidad absoluta fuera requerida por el que tiene interés en ello, el Fiscal de la Corte Suprema y los Fiscales de las Cortes de Apelaciones o declarada por el juez de oficio. Dicho de otra forma, existe la posibilidad que no sean las partes quienes la activen, de modo que no podría considerarse, en todos los supuestos en que ella proceda, un medio de tutela, toda vez que, si la invoca el ministerio público o la declara el juez de oficio, tendrá lugar aun cuando la voluntad de los contratantes sea tener por válido un acto nulo.

Esta constatación no significa que la nulidad no sea una medida de protección, toda vez que, dependiendo del caso, ella tutela el orden jurídico o a ciertas personas que están en situación de inferioridad ${ }^{33}$. Y es que, la naturaleza jurídica de la nulidad debe ser una sola. Lo que ocurre es que, atendido el interés superior o general involucrado, el alcance de la tutela que ella otorga varía, pues en el caso de la nulidad absoluta no se circunscribe a las partes involucradas, como acontece en la relativa que resguarda el interés particular de ellas, sino que tiene un espectro más amplio, cual es el interés de la sociedad o colectividad ${ }^{34}$. De allí que podamos calificarla como un mecanismo de protección, superando, al igual que acontecía con la nulidad relativa, la naturaleza jurídica sancionatoria que se le ha atribuido tradicionalmente, pero no concebirla como un medio de tutela del contratante perjudicado, porque estaríamos desconociendo la finalidad supraindividual que el legislador ha perseguido al tipificarla y, por lo mismo, la posibilidad que opere al margen de la voluntad de las partes del contrato.

Con todo, podría indicarse que, en realidad, la legitimidad que contempla el artículo 1683 para impetrar la nulidad absoluta es irrelevante, porque una interpretación más reciente aboga por su operatividad ipso iure. Pero si tal premisa es efectiva, como lo intentaremos demostrar en el apartado siguiente, el problema no sólo se

\footnotetext{
${ }^{32}$ Dicotomía que también ha sido acuñada por la doctrina venezolana, colombiana y argentina. En tal sentido véase Fenoy Picón (2017, pp. 603-605) y Severin Fuster (2017, p. 1513, n. 88).

${ }^{33}$ Por todos Ducci Claro (1988, p. 315), Vial del Río (2003, p. 248) y Alessandri Besa(2008, p. 20).

${ }^{34}$ Alessandri Besa (2008, p. 101-102) y Baraona González (2012, pp. 47-48).
} 
mantiene, sino que se agudiza, toda vez que la nulidad absoluta ni siquiera podría ser invocada por los contratantes, de modo que tampoco cabría sostener que se trata de un medio de tutela.

\subsubsection{La operatividad de pleno derecho de la nulidad absoluta}

Una lectura preliminar y literal de nuestro Código Civil podría revelar que la nulidad absoluta requiere declaración judicial, toda vez que, como ya hemos precisado, el artículo 1683 impone al juez tal deber cuando aparece de manifiesto en el acto o contrato y faculta a todo el que tenga interés en ello, salvo la excepción que referimos precedentemente, a solicitar su declaración y al ministerio público a invocarla en el interés de la moral y de la ley (Claro Solar, 1939, p. 603) ${ }^{35}$.

Sin embargo, a partir de ciertos preceptos contenidos en él y determinados argumentos dogmáticos formulados recientemente ${ }^{36}$, es posible arribar a la conclusión contraria. En efecto, un detenido examen de la historia fidedigna del establecimiento de la nulidad absoluta, la interpretación lógica de los artículos 705, $1470 \mathrm{~N}^{\circ} 1$ y $3,1471,1545,1682$ inciso final y 2375 y la necesidad de evitar dilatados y costosos pleitos nos sugieren que debe desterrarse dicha premisa y reemplazarse por la idea que tal declaración sólo es necesaria para activar el efecto restitutorio si las obligaciones emanadas del acto nulo se han cumplido, puesto que se trata de un medio de tutela que se activa ipso iure verificada la causal establecida por el legislador.

Y es que, más allá de considerar que subordinar la inexistencia del acto a la declaración judicial es una ficción contraria a la naturaleza y sin fundamento legal alguno (Fabres, 1908, pp. 144-145), existen, al menos, un argumento histórico, de texto y de utilidad que revelan tal operatividad y que, por los mismo, nos permiten sostener que la nulidad absoluta no constituye un medio de tutela del contratante perjudicado, dado que éste no podría solicitar o demandar su declaración, sino que ella simplemente se activaría por la verificación de alguna de sus causales.

En primer lugar, una indagación de los Proyectos que antecedieron a la versión actual del Código Civil permite constatar que existen sólidos antecedentes para sostener que el espíritu del legislador fue concederle una operatividad de pleno derecho a la nulidad absoluta, atendida probablemente la gravedad de las causales que determinan su procedencia. Ilustrativa es la historia fidedigna del artículo 1683 del Código Civil, pues revela que, en su primera versión contenida en el artículo 3 del Proyecto de 1842, ésta no podía sanearse por el transcurso del tiempo, admitiéndose esta posibilidad en el artículo 1866 del Proyecto Inédito y quedando así en la versión definitiva. Con todo, un análisis más detenido muestra que no se trataría de un plazo de prescripción de la acción de nulidad sino de extinción o caducidad del derecho a impugnar el acto, consolidándose los desplazamientos patrimoniales derivados del acto anómalo a través de la prescripción adquisitiva. Por consiguiente, la expresión

\footnotetext{
${ }^{35}$ Por todos.

${ }^{36}$ Fabres (1908, pp. 145-170), Rodríguez Grez (1995, p. 129), a propósito de las nulidades originarias, Alcalde Silva (2010, p. 69), Baraona González (2012, pp. 50-63) y San Martin (2015, pp. 769-770) y López Díaz (2017c, pp. 475-476), tratándose de la nulidad absoluta y relativa.
} 
saneamiento empleada en el artículo 1683 no aludiría a la desaparición del vicio del acto $^{37}$ y la legitimación de éste sería una consecuencia del transcurso del tiempo.

A ello se agrega que, un examen de la primera versión del actual artículo 1681 contenida en el Proyecto de 1842 y el párrafo 36 del Mensaje del Código, arrojarían que, para Bello, la nulidad relativa rescindía el acto, esto es, lo privaba de efectos, no así la nulidad absoluta, de modo que esta última tendría carácter ipso iure o automático (San Martín Neira 2015, pp. 769-770). En efecto, el artículo 10 del Proyecto de 1842 indicaba que "la nulidad debe ser judicialmente declarada", exigencia que fue suprimida en el Proyecto de 1853. De otro lado, el párrafo 36 del Mensaje, interpretado a contrario sensu, revela la misma idea, pues, en su parte pertinente, indica que se han seguido los Códigos Civiles francés, de las dos Sicilias y el sardo "en el sentido que en ellos el contrato celebrado por un menor sin el consentimiento del guardador no es nulo ipso iure, aunque puede rescindirse" (Baraona González, 2012, p.65).

Una segunda premisa que justifica inclinarse por la operatividad ipso iure de la nulidad absoluta es la interpretación lógica de diversos artículos que se refieren a ella en el Código Civil a propósito de la validación de un título posesorio que en principio fue nulo, las obligaciones naturales nulas y sus efectos, la fuerza obligatoria del contrato y la regla residual que prevé las causales de nulidad relativa ${ }^{38}$, toda vez que, a falta de un precepto específico que indique cómo se activa la nulidad absoluta, tal interpretación permitiría arribar a esta regla. Y es que los artículos 704 N³ y 705 evidenciarían que el título injusto que adolece de nulidad lo es $a b$ initio, puesto que, el primero, no la exige y, el segundo, emplea la expresión "en su principio fue nulo", de modo que no requiere sentencia judicial que así lo declare. El mismo fenómeno revelan, más allá de la discusión que su tenor literal ha suscitado en la doctrina nacional ${ }^{39}$, los artículos $1470 \mathrm{~N}^{\circ} 1$ y N³, 1471 y 2575 relativos a las obligaciones naturales nulas, a partir de las expresiones "contraídas", "proceden", "no extingue la obligación natural" y "no se ha validado por la ratificación o lapso de tiempo" que, respectivamente, emplean.

Por otra parte, el artículo 1545 apuntaría en igual dirección, toda vez que tal precepto recogería la expresión "invalidado" en términos amplios (no como sinónimo de nulidad), de modo que el "contrato legalmente celebrado" y obligatorio para los contratantes sería aquél que lo ha sido de conformidad a la ley y no el contrato nulo que, por consiguiente, no requiere ser privado de efectos, porque nunca los ha tenido. De otro lado, el último inciso del artículo 1682 al prescribir que "cualquiera otra especie de vicio produce nulidad relativa, y da derecho a la rescisión del acto o contrato" evidenciaría que sólo la nulidad relativa acarrea la rescisión, esto es, la privación de los efectos del acto, porque como la nulidad absoluta opera de pleno derecho no podría producir este efecto.

Por último, es posible invocar un argumento de utilidad en favor de la operatividad de pleno derecho de la nulidad, cual es la eficiencia jurídica y económica que ésta conlleva. Jurídica, en atención a dos consideraciones: de un lado, otorga certeza

\footnotetext{
${ }^{37}$ Baraona González (2012, pp. 55-59) y San Martín Neira (2015, pp. 760-762, 777-778).

${ }^{38}$ Baraona González (2012, pp. 59-62) y San Martín Neira (2015, pp. 769-770).

39 Por todos Abeliuk Manasevich (2014, pp. 423-426).
} 
a la celebración de un acto que, aparece como jurídico, pero que carece de fuerza obligatoria y del que se predica una validez provisional hasta que la declaración judicial no se efectúe (Baraona González, 2012, pp. 50-63) ${ }^{40}$ y, de otro refuerza la posición del sujeto protegido, dado que no deberá recurrir a tribunales, sino tan sólo invocar que ésta ha operado, favoreciendo a los terceros que pueden invocarla para defender sus intereses, como acontece con el codeudor solidario y subsidiario(Jerez Delgado $\left(2011\right.$, p. 58-60, 190) ${ }^{41}$. Económica, pues si bien existirán casos en que se requerirá declaración judicial, como sucede en aquellos en que se quiere vencer la resistencia de quienes sostienen la validez del acto y borrar tal apariencia, deviniendo la sentencia en declarativa (De Castro y Bravo 1985, p. 475), la desjudicialización indiscutidamente evita dilatados y costosos pleitos, aliviando las finanzas de los eventuales involucrados y la recarga de causas que actualmente existe en los tribunales de justicia.

Pues bien, en atención a los argumentos que hemos venido refiriendo, debe concluirse que la sentencia judicial que se pronuncia en un juicio de nulidad tendría un carácter declarativo y permitiría, por una parte, exigir la restitución de lo entregado en virtud del contrato anulado y, por otra, otorgarle independencia a la acción restitutoria respecto de la acción de nulidad. Y es que, como acertadamente indica el profesor Baraona González (2012, pp. 53-55), no puede entenderse que por la declaración de nulidad un acto válido pasa a ser nulo, pues ello supondría privar de completo sentido a las normas imperativas y prohibitivas. Lo que tal declaración acarrea es la exigibilidad del deber del deudor de restituir y del derecho del acreedor a solicitar tal restitución, toda vez que se ha destruido la apariencia de regularidad del acto o contrato que autorizaba la retención de lo recibido indebidamente (Jerez Delgado $(2011, \text { p. 99 })^{42}$. Es precisamente esa la premisa a partir de la cual debe fijarse el correcto sentido y alcance de los artículos 1687 y 1689 del Código Civil, diluyéndose así la pretendida exigencia de declaración judicial de la nulidad por la que ha abogado nuestra doctrina mayoritaria y prevalente.

\section{Conveniencia de otorgarle a la nulidad relativa una naturaleza tuitiva}

Asentadas las premisas en virtud de las cuales se justifica concebir la nulidad relativa como medio de tutela y desestimar tal calificación para la nulidad absoluta, cabe preguntarse cuál es la conveniencia de adoptar este enfoque, pues podría pensarse que atribuirle esa naturaleza sólo sienta las bases para articularla en el sistema de tutela precontractual junto a la adaptación del contrato y a la indemnización de daños (López Díaz, 2017c, pp. 473-477).

Sin embargo, un análisis más detenido de la nulidad y el sistema de protección del acreedor revela que este enfoque reviste una importancia teórica y práctica evidente, puesto que permite alcanzar dos objetivos tan relevantes como aquél: (i)

\footnotetext{
${ }^{40}$ Siguiendo y complementando la tesis de Fabres (1908, pp. 145-170)

${ }^{41}$ Destacando estas ventajas a propósito de la nulidad relativa.

${ }^{42}$ En igual sentido.
} 
prescindir de su declaración judicial, concibiéndola como una forma de autotutela y (ii) admitir su eventual concurrencia con la resolución por incumplimiento y contrastar la tutela que ambas dispensan al acreedor. Por el contrario, si se le confiriera un carácter sancionatorio, no podría incardinarse con los otros medios de tutela precontractuales, sería más complejo descartar su ejercicio judicial (puesto que la finalidad perseguida no sería tutelar al perjudicado sino castigar el acto y la sentencia haría efectiva tal sanción, declarando su ineficacia) y, finalmente, no podría compararse el alcance de su tutela con aquel propio de la resolución, pues se trataría de un cotejo entre distintas especies.

\subsection{Permite prescindir de su declaración judicial}

Una de las grandes novedades introducidas por el movimiento de modernización del derecho de obligaciones y contratos es establecer el ejercicio extrajudicial de medios de tutela que los Códigos Civiles decimonónicos habían perfilado como judiciales, con el propósito de otorgar una protección más acabada al acreedor, pues sólo tendría que notificar su decisión al deudor. Es el caso de la resolución por incumplimiento, como lo revelan los artículos 9:303 de los PECL, III.- 3:507 del DCFR, 7.3.2 de los PICC, 1199 inciso segundo de la PME, 518-13.2 de la PAPDC, modelo cuya conveniencia ya ha sido sugerido entre nosotros en determinados casos (Pizarro Wilson, 2007, pp. 21-28) y que podría cobrar más fuerza a partir de la incorporación del artículo 1226 del Code que, a partir de la Ordenanza № 2016-131 de 10 de febrero de 2016, la prevé.

Un fenómeno similar se advierte tratándose de la nulidad, toda vez que, como apuntamos precedentemente, en la última década las propuestas de modernización del derecho de obligaciones y contratos han adoptado esa modalidad, como lo evidencian los artículos 1296 de la PME y 527-1 de la PAPDC que establecen la operatividad de pleno derecho de la nulidad absoluta. La interrogante que surge, entonces, es si es correcto pensar que debe intentarse una relectura de los artículos $1567 \mathrm{~N}^{\circ} 8$, 1687 y 1689 del Código Civil que aluden a su declaración por sentencia judicial ${ }^{43}$ para abogar por la desjudicialización de la nulidad relativa y, si es posible, inclinarnos por dicha alternativa.

A nuestro juicio, la respuesta es afirmativa y puede sustentarse a partir de una categoría dogmática que hemos referido más arriba: la autotutela. Y es que si recordamos que la nulidad es un medio de tutela del contratante perjudicado, fácil es advertir, como lo ha sostenido contundentemente la doctrina española más reciente (Jerez Delgado, 2011, pp. 72-83), a partir de lo preceptuado en los artículos 4:112 de los PECL, II.- 7:209 del DCFR, 3.2.12 de los PICC, 1305 de la PME y 527-13 de la PAPDC, que ésta constituye una forma de autotutela que emana del derecho potestativo que tiene aquél para anular o confirmar el contrato.

\footnotetext{
${ }^{43}$ Y la exigirían para extinguir las obligaciones incumplidas (art. $1567 \mathrm{~N}^{\circ} 8$ ), restituir a las partes al estado en que se encontrarían de no haber celebrado el acto (art. 1687) y otorgar acción reivindicatoria respecto de terceros poseedores (art. 1689).
} 
La modalidad que podría adoptar esta declaración de voluntad unilateral y recepticia sería la que ha acuñado el moderno derecho de los contratos, esto es, la de una notificación no sujeta a formas especiales, pero realizada a través de medios idóneos y eficaces para que el destinatario tome conocimiento de aquella ${ }^{44}$. Otra alternativa, menos radical, sería abogar por la modalidad bilateral regulada en el artículo 1178 del Code que faculta a las partes a constatarla, siempre que procedan de común acuerdo, manteniendo la regla en virtud de la cual "la nulidad será pronunciada por el juez", pero introduciendo como excepción el consenso de las partes. Con todo, tal fórmula ha sido criticada, porque se aparta del carácter judicial de la nulidad, resulta incoherente con el régimen de la resolución unilateral previsto en el inciso primero del artículo 1226 del Code y deja abierta la puerta para que la nulidad por notificación adquiera reconocimiento jurisprudencial y se instale en el derecho francés, como aconteció antes de esta reforma con la resolución por incumplimiento ${ }^{45}$.

Este cambio de paradigma del Code, precursor y acérrimo defensor de la declaración judicial por más de dos siglos, junto a la constatación que la nulidad absoluta opera de pleno derecho, nos invita a repensar si efectivamente existe en nuestro Código una exigencia de declarar judicialmente la nulidad relativa. $O$ debemos desestimarla a partir de la ausencia de una norma que así lo establezca, de las razones de eficiencia jurídica y económica indicadas a propósito de la nulidad absoluta y de la idea que la nulidad es un medio de tutela, que, en cuanto tal, confiere un derecho potestativo al contratante perjudicado para solicitar o confirmar la nulidad relativa, como lo revelan los artículos 1684 y 1693 a 1697 de nuestro Código Civil.

La conveniencia de este enfoque es evidente, pues refuerza la tutela del contratante protegido, reconociéndole su derecho a invocar la invalidez del contrato, forzando al otro contratante a acudir a tribunales y probar su eficacia si pretende exigir su cumplimiento. De otro lado, si éste se niega a restituir lo recibido en virtud del contrato, deberá la indemnización por el retraso desde que extrajudicialmente se manifestó la voluntad de anularlo. Fortalece, además, la seguridad jurídica al poner término a la incertidumbre respecto de la situación del contrato anómalo, pues una vez anulado no puede ser confirmado. Y, al igual que acontecía con la nulidad absoluta, favorece a los terceros, como el deudor solidario o el fiador, que puedan invocar la nulidad para defender sus intereses (Jerez Delgado, 2011, pp. 58-60, 190).

Abogar por la operatividad automática de la nulidad absoluta o la modalidad extrajudicial de nulidad relativa no obsta a que, en caso de desacuerdo, las partes puedan recurrir a la judicatura para que sea ésta la que determine si el contrato debe o no anularse. Y es que, como hemos apuntado más arriba, reconocer la extrajudicialidad de la nulidad tan sólo evidencia que la sentencia judicial tiene carácter declarativo y que ella admite una doble justificación: permitir a quien demanda la nulidad exigir la restitución de lo entregado en virtud del contrato anulado y distinguir la acción de nulidad de aquella restitutoria que durante décadas se han amalgamado innecesariamente.

\footnotetext{
${ }^{44}$ Un análisis comparativa de esta modalidad en Jerez Delgado (2011, 152-168).

${ }^{45}$ Deshayes, Genicon y Laithier (2016, pp. 325-326) y Chantepie y Latina (2016, p. 390).
} 


\subsection{Justifica la confluencia de la nulidad relativa con la resolución por incumplimiento}

El examen de la nulidad no estaría completo si no se indagara su eventual concurrencia con la resolución por incumplimiento, toda vez que es posible que determinadas causales de nulidad relativa, tales como el error sustancial ${ }^{46}$, error accidental y el dolo, confluyan con aquellas propias de la resolución en un mismo supuesto de hecho, pudiendo el acreedor, en principio, inclinarse por una u otra indistintamente.

Tal convergencia, como se advertirá en las líneas que siguen, encuentra justificación en el hecho que tanto la nulidad como la resolución, persiguen, con mayor o menor intensidad, según nos inclinemos por la doctrina clásica que postula el efecto retroactivo de la resolución o la moderna que aboga por un retroactividad limitada, una finalidad aniquilatoria, de modo que integran un mismo binomio tuitivo. Se trata del efecto más radical derivado de la activación de un medio de tutela que contrasta con la conservación del contrato a la que propenden, en sede precontractual, la nulidad parcial, la confirmación de la nulidad relativa y la conversión del acto nulo y, en la fase contractual, la imprevisión, la rebaja del precio y algunos casos de indemnización autónoma (López Díaz, 2015, pp. 352-356).

\subsubsection{Supuestos de procedencia}

Como ya lo hemos consignado en las líneas precedentes, nuestro Código Civil contempla como causales de nulidad absoluta, en los incisos primero y segundo del artículo 1682, el objeto o causa ilícita, la omisión de algún requisito o formalidad que las leyes prescriben para el valor de ciertos actos o contratos en consideración a la naturaleza de ellos y los actos y contratos de los absolutamente incapaces. Y, de otro lado, indica en el inciso final que "cualquiera otra especie de vicio produce nulidad relativa", cláusula que según la opinión mayoritaria, comprende los vicios del consentimiento, la omisión de formalidades habilitantes, los actos irregulares de los relativamente incapaces y, discutiblemente, la lesión enorme ${ }^{47}$. No acontece lo mismo tratándose de la resolución por incumplimiento, motivo por el cual nuestra doctrina, a partir del modelo adoptado por las propuestas de modernización de derecho de obligaciones y contratos que hemos mencionado en esta investigación, ha ensayado una relectura de diversas disposiciones del Código Civil, concluyendo que ésta procede si las partes han estipulado a través de una cláusula resolutoria que un determinado incumplimiento tendrá ese carácter, en el evento que la inejecución prive al acreedor de los beneficios que esperaba obtener con la celebración del contrato o el incumplimiento determine la pérdida de confianza del acreedor en el futuro cumplimiento de su deudor. ${ }^{48}$

\footnotetext{
${ }^{46}$ Caprile Biermann (2008, p. 571-601), Baraona González (2008, p. 668-669) y De la Maza Gazmuri (2014, pp-141-159).

${ }^{47}$ Por todos Alesssandri Besa (2008b, pp.72-83). En lo que concierne a la controversia respecto de la lesión enorme López Díaz (2017b, pp 685-699).

${ }^{48}$ Vidal Olivares (2009, p. 253-254) y Mejías Alonzo (2011, pp. 212-277).
}

Rev. derecho (Coquimbo, En línea) 2019, 26: e3597 
Pues bien, un examen de todas ellas revela que los supuestos de hecho en que indiscutiblemente pueden concurrir la nulidad y la resolución son el error sustancial, error accidental, error en la persona y el dolo, pues todas ellas configuran, a la vez, la frustración del propósito práctico perseguido por el acreedor, privándolo de los beneficios que esperaba obtener del contrato. No acontece lo mismo tratándose de las cláusulas resolutorias, dado que, aun cuando el incumplimiento pactado como resolutorio configure una causal de nulidad, prevalece la autonomía de la voluntad, de modo que el acreedor sólo podrá instar por la resolución. Un fenómeno similar se aprecia a propósito de la pérdida de confianza del acreedor, pues ésta se configura si ha existido un incumplimientos doloso, cometido con culpa grave y reticente o una inejecución de las obligaciones derivadas de contratos intuito personae (Mejías Alonzo, 2011, pp. 254-277), lo que supone que el contrato se celebre válidamente, sin que pueda proyectarse el dolo vicio a su incumplimiento.

Con todo, podría pensarse que, atendido que el artículo 1469 prohíbe renunciar anticipadamente a la nulidad, éste constituiría un obstáculo a la confluencia que venimos proponiendo. Sin embargo, ello dependerá de la interpretación que se le otorgue a dicho precepto. En efecto, si se considera que éste sólo resulta aplicable a la nulidad absoluta, bajo la premisa que, como la nulidad relativa pude confirmarse procedería su renuncia en cualquier momento (incluso anticipadamente), el legitimado para impetrarla sólo tendría como alternativa inclinarse por la resolución del contrato, en circunstancias que los supuestos de nulidad relativa son aquellos que demandan mayor protección. En cambio, si como creemos, dicha disposición procede respecto de todo tipo de nulidad, el acreedor seguiría teniendo la posibilidad de optar entre la nulidad y la resolución.

Pareciera ser que esta segunda interpretación es la más acertada, en atención, al menos, a tres argumentos. En primer lugar, porque el artículo 1469 consagra un principio de la nulidad que se asienta en la idea que ella constituye una medida protectora del orden jurídico y de ciertas personas que se encuentran en situación de inferioridad y, en cuanto tal, es irrenunciable a priori, pues de lo contrario se convertiría en una cláusula de estilo que permitiría a las partes hacer caso omiso de las disposiciones imperativas de la ley ${ }^{49}$. De otro lado, el legislador no distingue en tal artículo a qué tipo de nulidad se refiere ni la circunscribe a una en particular, de modo que no sería lícito al intérprete restringir su alcance. Más aún, si se ubica con antelación a la distinción entre nulidad absoluta y relativa que el Código efectúa en el artículo 1681. Por otra parte, lo que se prohíbe es la renuncia anticipada, esto es, aquella que tiene lugar antes que se materialice el vicio; en cambio, la confirmación procede con posterioridad a la constatación de éste, de modo que no pueden equipararse ${ }^{50}$. Finalmente, si la aplicación del artículo 1469 sólo se restringiera a la nulidad absoluta y, por consiguiente, se admitiera la renuncia anticipada de la relativa, podría ocurrir que, quien la efectúa se percatara, con posterioridad, que fue víctima de dolo y que, por esa vía, ha condonado el dolo futuro. En tal caso, dicho precepto estaría permi-

\footnotetext{
${ }^{49}$ Por todos Ducci Claro (1988, p. 315), Vial del Río (2003, p. 248) y Alessandri Besa (2008, p. 20).

${ }^{50}$ La proscripción de la renuncia anticipada se repite con cierta frecuencia en el Código. Piénsese en la prohibición de condonar el dolo futuro (art. 1465) o renunciar anticipadamente a la prescripción (art. 2494).
} 
tiendo realizar lo que el artículo 1465 precisamente prohíbe, lo que resulta inadmisible.

\subsubsection{El error vicio}

Un examen de nuestra literatura jurídica revela que el error sustancial, tipificado en el artículo 1454 del Código Civil, ha sido el supuesto de confluencia más profusamente explorado por la dogmática nacional ${ }^{51}$, abandonándose la antigua idea según la cual éste sería desplazado por la pretensión resolutoria (Alessandri Besa, 2008 b, p. 33). Y es que, no cabe duda que la falsa representación de la sustancia o las calidades esenciales de la cosa objeto del contrato puede constituir, a la vez, una causal de resolución por incumplimiento, puesto que esa discordancia frustra el interés del acreedor.

Tal sería el caso si una empresa celebra un contrato de compraventa con otra en virtud del cual esta última se obliga a entregarle dos camiones Mercedes Benz correspondientes a los años 2000 y 2001 y, transcurridos cinco meses desde la celebración del contrato, se detecta que fueron fabricados en 1997 y 1998, respectivamente, como aconteció en el caso C.T.T.con T.T.R. (19 de enero 2010). ${ }^{52}$. Un fenómeno similar se advierte en S.A.S.A. con F.M.S.A.(7 de octubre 2017)en que se celebró un contrato de compraventa de animales vivos con el propósito de faenarlos y exportar su carne para consumo y, realizada la entrega, se detectó en la carne sustancias tóxicas para el consumo humano, motivo por el cual se ordenó su decomiso y posterior destrucción, impidiendo su comercialización ${ }^{53}$. Otro tanto acontece si el predio arrendado no está destinado a la realización de actividades comerciales o no ha sido urbanizado ni se ha emitido permiso de edificación ${ }^{54}$, como sucedió en G.I.L. con C.I.D.S.S.A (19 de enero de 2008). En este último caso, a diferencia de los anteriores, en que se impetró la nulidad por error sustancial, el arrendatario demandó la terminación del contrato de arrendamiento de un predio urbano con indemnización de daños, porque si bien se estipuló que lo destinaría a explotar una cancha de minigolf, no fue posible, pues no se encontraba urbanizado ni tenía permiso de edificación y recepción final y una franja estaba sujeta a expropiación ${ }^{55}$.

Una situación similar se puede advertir tratándose del vendedor que entrega al comprador las latas de aceite de oliva estipuladas, el fertilizante pactado o determinadas piezas de níquel, pero con una composición distinta, como acontecería si las latas fueran de aceite vegetal, el fertilizante contuvieran una alta concentración de boro que daña irreparablemente la plantación al que estaba destinado o las referidas piezas no fueran de níquel. En todos estos supuestos, no sólo se advierte la ausencia de una cualidad sustancial de la cosa objeto del contrato, sino que un cumplimiento imperfecto reconducible al aliud pro alio que hace procedente la resolución ${ }^{56}$. Mira-

\footnotetext{
${ }^{51}$ De la Maza Gazmuri (2011, pp. 218-220) y De la Maza Gazmuri (2014, pp. 136-137 y 146-148).

${ }^{52}$ Comentado por De la Maza Gazmuri (2011, pp. 218-220).

${ }^{53}$ Comentado por De la Maza Gazmuri (2015).

${ }^{54}$ Mejías Alonzo (2011, pp. 242-263) y De la Maza Gazmuri (2011, pp. 220-225).

${ }^{55}$ Comentado por De la Maza Gazmuri (2011, pp. 222-223).

${ }^{56}$ Así se desprende del inciso segundo del artículo 1814 que hace procedente la facultad del acreedor de resolver el contrato si "faltaba una parte considerable", dado que si éste puede ejercerla por inhabi- 
das las cosas desde esta perspectiva, será relevante la calificación de los hechos que realice al acreedor para diseñar su estrategia de protección, dado que si su interés es privar al acto de efecto abogará por la nulidad relativa; pero si persigue su aniquilación limitada se inclinará por la resolución. Volveremos sobre este punto.

Lo propio puede ocurrir con el error accidental o el error en la persona, en la medida que éstos vicien el consentimiento, esto es, concurran los requisitos del inciso segundo del artículo 1454 y 1455 del Código Civil, respectivamente ${ }^{57}$. Así acontecería si las cualidades de la cosa objeto del contrato fueran accidentales, pero constituyeran el principal motivo de una de ellas para contratar y éste fuera conocido por la otra parte. Piénsese en el color, fecha o antigüedad, pues, por regla general, si no existe acuerdo en tal sentido, éstos son irrelevantes. O si la identidad o cualidades de la persona del otro contratante fuera determinante a tal efecto, ya que, en ambos casos, las calidades que no concurren se incorporaron al contrato - en tal sentido véase De la Maza Gazmuri(2011, p. 218)-, de modo que se configuraría un incumplimiento.

En cambio, no se advertiría confluencia alguna entre la nulidad y la resolución tratándose del error esencial u obstáculo que regula el artículo 1453, toda vez que, éste se verifica si la falsa representación de la realidad recae sobre la especie del acto o contrato que se ejecuta o celebra. Y es que, independientemente que se adhiera a la postura que señala que por razones prácticas, éste acarrea la nulidad relativa del acto o contrato ${ }^{58}$ y no su inexistencia, tal error no constituye una causal de resolución, dado que, como las voluntades no se encuentran, no existe contrato susceptible de incumplirse.

\subsubsection{El dolo vicio}

Finalmente, es posible que el dolo vicio pueda constituir no sólo una causal de nulidad relativa si cumple los requisitos del artículo 1458, esto es, cuando es obra de una de las partes y aparece que sin él la otra no hubiera contratado, sino de resolución por incumplimiento. Así acontecerá en los casos de error sustancial referidos precedentemente si el contratante perjudicado incurre en él porque el otro, a través de una maquinación fraudulenta lo induce a contratar, manifestando que los camiones fueron fabricados el año 2000 y 2001, que el predio arrendado se encontraba urbanizado y contaba con permiso de edificación o que la carne de cerdo se encontraba en perfecto estado, en circunstancias que estaba en conocimiento que su de-

lidad parcial del objeto, con mayor razón estará facultado cuando dicha inhabilidad sea total. A nuestro juicio, tal expresión sólo evidenciaría que el legislador subordina la procedencia de este medio de tutela a la privación sustancial de los beneficios que esperaba obtener con la ejecución del contrato, independientemente que falte una parte de la cosa (con tal que sea considerable) o la totalidad de ella. De modo que podría agregarse a los artículos 1590, 1858, 1868 y 1928 a partir de los cuales se ha construido esta causal de resolución (Vidal Olivares, 2009, p. 246, n. 74) y (Mejías Alonzo, 2011, p. 137, n. 239). Incluso en un análisis más acucioso aún podría estimarse que se configura un supuesto falta de objeto y, en tal caso que procede la nulidad absoluta. Véase López Díaz (2017d, pp. 61-62).

${ }^{57}$ cft. Martinic Galetovic y Reveco Urzúa (2005, p. 289), quienes sostienen que si se configura dicho error el juez deberá dar lugar a la nulidad relativa.

${ }^{58}$ Una síntesis de esta discusión en Vial del Río (2003, pp. 90- 91) y Martinic Galetovic y Reveco Urzúa (2005, pp. 282-283). 
claración era falsa. O bien omite indicarle que los camiones, predio y carne de cerdo adolecían de dichas anomalías, sabiendo que, de conocerlas, el deceptus no hubiera contratado.

Un fenómeno similar se advierte si la vendedora engaña a la compradora respecto de la posibilidad de utilizar los servicios ofrecidos en un contrato de programa vacacional ${ }^{59}$ o sobre el contenido de un determinado curso o capacitación laboral, toda vez que existe una disconformidad que frustra el propósito que perseguía al celebrar el contrato. Otro tanto acontece si en un anuncio publicita una carrera o una alarma con "grabación de imágenes 24 horas", en circunstancias que, en el primer caso el campo ocupacional es inexistente y, en el segundo, la grabación de imágenes sólo tiene lugar si ésta se activa (De la Maza Gazmuri, I. 2015, pp. 558-560, 568-569).

En tales supuestos existirá publicidad engañosa, regulada en el artículo 28 de la Ley 19.496 sobre Protección de Derechos de los Consumidores, hipótesis en la cual el comprador podrá demandar la nulidad por dolo, pero también, en lo que aquí interesa, la resolución por incumplimiento por privación de los beneficios que esperaba obtener del contrato, en la medida que la publicidad se haya integrado al contrato, lo que sucederá si el destinatario conocía la publicidad, ésta fue determinante en su decisión de contratar y pudo confiar razonablemente en ella (De la Maza Gazmuri, 2015, pp. 521-571).. Y es que, en tal caso, a diferencia de la publicidad engañosa cuya tipificación pretende, prevalentemente, no sólo tutelar a los consumidores sino resguardar la transparencia del mercado ${ }^{60}$, se verifica una falta de conformidad, pues el deudor no entregó aquello a que se obligó (De la Maza Gazmuri, 2013, p. 433, n. 8), advirtiéndose un incumplimiento esencial que activa la resolución.

\section{La opción entre la nulidad relativa y la resolución por incumpli- miento}

Establecidos los supuestos en que podría concurrir la nulidad relativa y la resolución por incumplimiento, surgen, al menos, dos interrogantes: (1) ¿El contratante perjudicado efectivamente puede optar entre ellas? Y (2) ¿Es más conveniente inclinarse por la nulidad o por la resolución? Para responder la primera interrogante revisitaremos algunos argumentos dogmáticos (López Díaz, 2017d, pp. 69-77), circunscribiéndolos a este caso concreto y agregaremos otros que nos permitirán sustentar el derecho de opción desde una perspectiva normativa, a partir de determinados preceptos contenidos en nuestro Código Civil. Demostrada su procedencia, se indagará cuál es su relevancia, cotejando el alcance de una y otra.

\footnotetext{
${ }^{59}$ B.S.A. con C.S.A (29 de agosto de 2013), comentado por Prado López (2016, p. 443).

${ }^{60}$ Pues también protege la libre competencia, la lealtad en la competencia, la propiedad intelectual y los datos personales. De allí que se sostenga que el derecho de la publicidad comprende la libre competencia, la protección jurídica de los consumidores, la creación publicitaria y los derechos de la personalidad (Santaella López, 2003, p. 221).
} 


\subsection{Justificación dogmática del derecho de opción del contratante perju- dicado}

Como es ampliamente sabido, la discusión respecto de la procedencia del derecho de opción entre la tutela precontractual y contractual se ha suscitado a propósito de su regulación en las propuestas de modernización del derecho de contratos, específicamente a partir de lo preceptuado en los artículos 4:119 de los PECL y 49 de los PLDC y en el artículo 3.2.4 de los PICC. Los primeros la acogen indicando que no existen buenas razones para desestimarla y que a la parte perjudicada le puede resultar más simple recurrir a los medios de tutela precontractuales (Lando y Beale, 2003, p. 413). En tanto, el último la desestima tratándose de la nulidad por error, aduciendo que los medios de tutela contractuales otorgan una protección más efectiva al acreedor y son más flexibles que la nulidad ${ }^{61}$.

Sin embargo, más allá de este debate, existen, entre nosotros, argumentos dogmáticos y de texto que permiten justificar la opción del contratante perjudicado entre la nulidad y la resolución. Tales son el carácter sucedáneo de éste respecto del derecho de crédito, las dificultades probatorias a las que pueda verse enfrentado el acreedor en ambos sistemas de tutelas, la amplitud de mecanismos de protección, efectividad y flexibilidad tuitiva que éstos presentan, la existencia de determinados factores que justifican escoger entre ellos, pues inciden en el alcance de la tutela del acreedor (López Díaz, 2017d, pp. 69-77), y ciertos artículos en nuestro Código que así lo revelarían (López Díaz, 2018b). Cuestión distinta es que la parte demandada de resolución discuta la validez del contrato, porque se verifica, por ejemplo, un supuesto de error sustancial que la legitima para alegar la nulidad relativa y el juez deba decidir si acoge la pretensión que denuncia la inejecución del contrato o su invalidez, dado que, independientemente de cuál sea su decisión, el acreedor ha ejercido su derecho de opción.

En primer lugar, el derecho de opción es sucedáneo al derecho de crédito, toda vez que es la prolongación de éste, verificado el incumplimiento en sede contractual, de modo que, siguiendo la misma lógica, también viene a reemplazarlo en aquellos supuestos de anomalías o disconformidades acaecidas en la fase precontractual e, incluso, cuando éstas, a su vez, puedan reconducirse a un supuesto de inejecución. En consecuencia, desestimarlo equivaldría a conculcarle al acreedor la misma protección que el legislador pretendió otorgarle al tipificar diversos medios de tutela precontractuales y contractuales, salvo que su ejercicio contravenga sus límites sustantivos, cuales son la buena fe y el interés del deudor, y procedimentales, representado por la carga del acreedor de seleccionar la acción por la cual demanda, procurando la compatibilidad de sus pretensiones ${ }^{62}$.

De otro lado, puede resultar al acreedor más adecuado inclinarse por la tutela precontractual. Así acontecería en el evento que pueda acreditar la concurrencia de los presupuestos de un medio de tutela precontractual, pero no de uno contractual.

\footnotetext{
${ }^{61}$ Instituto Internacional para la Unificación del Derecho Privado (2010, p. 113).

${ }^{62}$ En lo que se refiere a los sustantivos véase López Díaz (2015, pp. 113-125) y para los procedimentales a Larroucau Torres (2015, pp. 273-279.
} 
Piénsese, por ejemplo, en el supuesto que sólo exista la posibilidad de acreditar el daño en el interés negativo y no en el interés positivo o probar la existencia de un vicio del consentimiento, mas no la frustración del interés del acreedor que da lugar a la resolución.

Por otra parte, la tutela precontractual no es necesariamente más amplia, efectiva y flexible que la contractual. En primer lugar, porque, como se ha consignado recientemente, en ambos sistemas existe pluralidad de medios de tutela (López Díaz, 2017d, pp. 55-69) ${ }^{63}$, advirtiéndose una coherencia tuitiva satisfactoria, aniquilatoria y resarcitoria entre ellos. De otro lado, la protección precontractual puede ser más efectiva y flexible que la contractual en aquellas hipótesis en que existiendo error vicio, el contratante perjudicado quiera hacer subsistir el contrato y no aniquilarlo. Claro está que si este error se proyecta a la fase contractual determinará la frustración del interés del acreedor y hará procedente la resolución por incumplimiento, aniquilando parcialmente el contrato. Pero la solución podría ser distinta si existiera error unilateral, esto es, uno de los contratantes lo experimenta y el otro manifiesta su disposición a cumplirlo o cumpliera el contrato tal cual había sido entendido por aqueIla, o error compartido, otorgándosele por las partes el sentido que razonablemente habrían acordado de no haber existido error, pues estaremos ante la adaptación del contrato, cuya procedencia se ha admitido entre nosotros (López Díaz, 2018), lo que permitirá su subsistencia.

A ellos se agrega la existencia de determinados preceptos contenidos en el Código Civil chileno, cuales son los artículos 1814, 1861 y 1932 que, a nuestro juicio, reconocen el derecho a escoger entre la tutela precontractual y la contractual (López Díaz, 2018b). Y es que, si bien el inciso final del artículo 1814 y el artículo 1861 contemplan la indemnización, no precisan si ésta es precontractual o contractual y, como no existe ningún elemento contenido en ellos que permita vincularla a una de tales fases, podría entenderse que tal determinación queda a elección del acreedor. En efecto, el artículo 1814 prevé la indemnización de daños en caso de venta, a sabiendas, de una cosa que, en todo o una parte considerable, no existía y el artículo 1861 consagra la pretensión indemnizatoria por vicios redhibitorios que puede proyectarse desde la fase precontractual a la contractual (López Díaz, 2016, pp. 690-682). Otro tanto se advierte a propósito del inciso primero del artículo 1932 relativo al arrendamiento, si el mal estado o calidad de la cosa al tiempo del contrato impide al arrendatario hacer uso de ella, dado que alude a la "terminación" o "rescisión" de éste, de modo que resulta evidente que el legislador no ha empleado esta última expresión como sinónima de "resolución" (pues ya se ha referido a "terminación"), sino que, probablemente, ha pretendido asimilarla a la nulidad relativa o a la rescisión en sentido estricto (López Díaz, 2017, pp.443-453) ${ }^{64}$, otorgándole el derecho de elegir entre la fase precontractual y contractual.

\subsection{Relevancia de la opción: tutelas aniquilatorias asimétricas}

\footnotetext{
${ }^{63}$ Aborda pluridireccionalmente los medios de tutela precontractuales y contractuales.

${ }^{64}$ Postula que la rescisión en sentido estricto es un medio de tutela precontractual. 
Establecida la procedencia de la opción entre tutelas, cabe dilucidar cuál es la conveniencia que ésta reporta al contratante perjudicado. Y la respuesta es que, si bien la nulidad relativa y la resolución por incumplimiento otorgan al contratante perjudicado una tutela aniquilatoria, el alcance es distinto, de modo que, dependiendo de cuál de ellas escoja, la intensidad de dicha protección será mayor o menor.

En efecto, en la nulidad la aniquilación o destrucción del contrato es absoluta o total, dado que ésta permite a los contratantes desvincularse del contrato; en cambio, en la resolución, es total o parcial, según la doctrina a la que se adhiera. Y es que, desde antiguo se ha postulado que la resolución opera con efecto retroactivo, a partir de la expresión "deberá restituirse" contenida en el artículo $1487^{65}$. Sin embargo, si nos plegamos a la tendencia más moderna, admitida por nuestra doctrina más reciente ${ }^{66}$, arribamos a una conclusión distinta, dado que recoge un modelo moderno que oscila entre el francés (que le otorga efecto retroactivo), y el anglosajón (que lo desconoce), atribuyéndole una retroactividad limitada a ciertas situaciones. La resolución no produciría, entonces, la desaparición de todos los efectos del contrato, sino la transformación de la relación obligatoria que debe liquidarse, a través de las restituciones que resulten procedentes. Ocurre que, a diferencia de la nulidad, el contrato efectivamente se celebró, pero se incumplió, de modo que no es posible volver al estado preexistente como si no se hubiera concluido. Esta nueva perspectiva permite entender la procedencia de la indemnización concurrente y la eficacia de las cláusulas penales o aquellas relativas a la solución de litigios o que deben surtir efecto después de la resolución (cláusulas de confidencialidad o no competencia) ${ }^{67}$.

Claro está que tal diferencia entre la nulidad y la resolución puede presentarse en los contratos de comodato o mutuo en que el efecto restitutorio es idéntico al cumplimiento, pero en que la nulidad acarreará, por ejemplo, la extinción de las cauciones que se hubieren constituido para garantizar el cumplimiento de la obligación convenida, efecto que ciertamente perjudicará al acreedor y que éste deberá considerar y ponderar al momento de inclinarse por una u otra.

Por otra parte, este cotejo entre nulidad y resolución evidencia que el alcance de la acción reivindicatoria sería diverso, dado que, de conformidad al artículo 1689 del Código Civil, ésta procede respecto de todos los terceros tratándose de la nulidad, no así en la resolución que sólo afecta a aquellos de mala fe, según lo prescriben los artículos 1490 y 1491. De otro lado, permite constatar que, como la nulidad opera con efecto retroactivo, siempre deben restituirse los frutos de la cosa, a menos que el poseedor esté de buena fe, lo que no acontecería en la resolución, dado que el artículo 1488 prescribe que esto ocurrirá si lo dispone el testador, donante, la ley o los contratantes. Con todo, recientemente se ha sostenido que las reglas del Título IV del Libro IV del Código Civil relativas a las obligaciones condicionales no se aplicarían a la resolución, advirtiéndose la necesidad de reconstruir su efecto restitutorio con el

\footnotetext{
${ }^{65}$ Por todos Vío Vásquez (1945, p. 368). Una visión panorámica en Pizarro Wilson (2012, pp. 450-453) y Mejías Alonzo (2016, pp. 275, 295-306).

${ }^{66}$ Pizarro Wilson (2012, pp. 457-460), Contardo González (2015, pp. 317-334), Alcalde Silva (2015, p. 579, 591-594, 600) y Mejías Alonzo (2016, pp. 271-322).

${ }^{67}$ Palazón Garrido (2014, pp. 158-169).
} 
carácter de íntegro ${ }^{68}$, admitiéndose la plausibilidad de la regla contenida en el artículo 1488 relativa a los frutos, no así aquellas referentes a la acción reivindicatoria de los artículos 1490 y 1491 (Alcalde Silva, 2019) ${ }^{69}$.

A dichas divergencias se agrega que el plazo de prescripción de las acciones de nulidad y resolutoria es indiscutiblemente distinto, sea que se acoja o no la desjudicialización de la nulidad. En efecto, en el caso de la nulidad relativa por error o dolo, de conformidad al artículo 1691, es de 4 años desde la celebración del acto o contrato. No acontece lo mismo en la acción resolutoria, pues a falta de regla especial, prescribe de acuerdo a aquella general contenida en los artículos 2514 y 2515, esto es, 5 años desde que la obligación se hizo exigible. Finalmente, en el evento que se adhiera al efecto ex nunc de la resolución se añade otra divergencia, toda vez que la liquidación del contrato que éste envuelve determina que, de intentarse una indemnización complementaria, ella comprenda el interés positivo y no el negativo, como acontecería si acompañara a la nulidad ${ }^{70}$.

La contraposición que hemos venido refiriendo será relevante para el acreedor, dependiendo de la situación en que se encuentre y el propósito que persiga al activar la tutela aniquilatoria en cuanto al alcance de la acción reivindicatoria, la restitución de los frutos y la posibilidad de impetrar la acción en un plazo mayor. Así, deberá considerar que esta última, si bien tiene un plazo de prescripción menor que la resolutoria, le permite reivindicar la cosa del tercer poseedor, independientemente de su buena o mala fe y recuperar los frutos de ella sin que se exija que la ley, testador, donante o contratantes lo dispongan, efectos que no se producen tratándose de pretensión resolutoria, cuyo plazo de prescripción es mayor y sólo permite reivindicar la cosa de terceros de mala fe.

Es más. Y es que probablemente decida inclinarse por la nulidad relativa y no por la resolución si pretende desligarse absolutamente del otro contratante, dado que el incumplidor podría oponer, durante toda la secuela del juicio, la excepción perentoria o anómala de pago contemplada en el artículo 310 del Código de Procedimiento Civil, haciendo subsistir el contrato y conculcándole al acreedor su derecho de opción (Elgueta Anguita, 1981, pp. 114-121). Miradas las cosas desde esta perspectiva, se diluiría en nuestro derecho el argumento propugnado por los comentaristas de los PICC a partir del artículo 3.2.4 que establece la incompatibilidad entre los medios de tutela precontractuales y contractuales en caso de nulidad por error, según el cual estos últimos otorgan una protección más efectiva al acreedor y son más flexibles que la nulidad (Instituto Internacional para la Unificación del Derecho Privado, 2012, p. 113). La posibilidad de enervar la acción resolutoria a través del pago constituiría, entonces, un factor específico que sólo incidiría en la opción del acreedor

\footnotetext{
${ }^{68}$ Alcalde Silva (2015, pp. 592-600) y Mejías Alonzo (2016, pp. 276, 287-288, 314).

${ }^{69} \mathrm{El}$ autor precisa que esta regla encuentra justificación en el hecho que el deudor debe devolver el provecho obtenido cuando ha desaparecido el título que justifica su percepción, lo que sólo ocurre cuando se verifica la resolución sin efectos retroactivos, indicando que mientras ella no se produzca, el deudor adquiere como propietario los frutos de acuerdo a las reglas generales. En lo que respecta a la acción reivindicatoria destaca que los artículos 1490 y 1491 no parecen satisfactorios para regular los efectos del ejercicio de la facultad resolutoria respecto de terceros.

${ }^{70}$ Un análisis en Contardo González (2015, pp. 317-334).
} 
en el binomio nulidad/resolución, agregándose a los argumentos que ya referimos para sustentar la opción del acreedor entre ambas tutelas y que, junto a aquél, viene a ratificar que ella debe mantenerse, especialmente, si un mismo supuesto de hecho activa la nulidad relativa y la resolución.

\section{Conclusiones}

De lo expresado en los párrafos precedentes es posible arribar a las siguientes conclusiones:

1. La nulidad relativa constituye un medio de tutela precontractual que encuentra su fundamento en la necesidad de tutelar al contratante que ha celebrado un contrato no querido o con un contenido no querido. No constituye, por tanto, una sanción, aun cuando su procedencia esté establecida por ley, toda vez que su objetivo no es castigar el acto viciado sino amparar a quienes se han vinculado a partir de éste, confiriéndole la facultad de aniquilarlo.

2. Adoptar este enfoque permite articularla junto a la adaptación del contrato e indemnización de daños, prescindir de su declaración judicial en cuanto forma de autotutela, y postular su eventual concurrencia con la resolución por incumplimiento. Si se le atribuyera un carácter sancionatorio no podría incardinarse con los otros medios de tutela precontractuales, sería más complejo descartar su ejercicio judicial y no podría contraponerse con la resolución, ya que se trataría de un cotejo entre distintas especies.

3. No es posible atribuirle este carácter a la nulidad absoluta, sea que se atienda a la legitimación para impetrarla o a su operatividad de pleno derecho. En efecto, si se adhiere a una lectura literal del artículo 1683 del Código Civil, como las partes no son las únicas facultadas para demandarla, puede operar aun cuando la voluntad de éstas sea tener por válido un acto nulo. En cambio, si se sostiene que ésta constituye una forma de ineficacia con efecto ipso iure el problema no sólo se mantiene sino que se agudiza, toda vez que la nulidad absoluta ni siquiera podría ser invocada por los contratantes, de modo que tampoco cabría atribuirle el carácter de medio de tutela.

4. Existen determinadas causales de nulidad relativa que pueden concurrir con la resolución por incumplimiento, puesto que privan al acreedor del beneficio que esperaba obtener con la celebración del contrato, supuesto en el cual este último puede inclinarse por una u otra, pero deberá considerar que la tutela aniquilatoria que ambas le otorgan es asimétrica, en cuanto a su alcance, procedencia de la acción reivindicatoria y restitución de los frutos.

\section{Agradecimientos}

Este trabajo forma parte del Proyecto FONDECYT de Iniciación N № 11150423 : "Hacia la articulación de un sistema de medios de tutela por responsabilidad precontractual en el Código Civil Chileno" del que la autora es investigadora responsable. 


\section{Referencias Bibliográficas}

Abeliuk Manasevich, R. (2014). Las obligaciones (6a ed., Vol. 1). Santiago: Thomson Reuters.

Alberruche Díaz-Flores, M. M. (2010). La rescisión por lesión en el derecho civil español. Madrid: La Ley.

Alcalde Silva, J. (2010). La rescisión en el código civil chileno. En Departamento de derecho privado Universidad de Concepción (Coord.), Estudios de derecho civil (Vol. 5, pp. 47-77). Santiago: Thomson Reuters.

Alcalde Silva, J. (2015). Bases para una sistematización de los efectos de la resolución por incumplimiento. En Á. Vidal Olivares, G. Severin Fuster y C. Mejías Alonzo (Eds.), Estudios de derecho civil (Vol, 10, pp. 570-600). Santiago: Thomson Reuters.

Alcalde Silva, J. (2019). “El contenido de la restitución derivada de la resolución por incumplimiento". En R. Saavedra Alvarado y L. F. Peuriot Canterini (Eds.), Libro homenaje a Leslie Tomasello (En prensa). Valparaíso: EDEVAL.

Alessandri Besa, A. (1949). La nulidad y la rescisión en el derecho civil chileno: título XX del libro IV del código civil. Santiago: Ediar. Recuperado de http://bit.ly/2LB4f9

Alessandri Besa, A. (2008). La nulidad y la rescisión en el derecho civil chileno (3a ed., Vol. 1). Santiago: Editorial jurídica de Chile.

Alessandri Besa, A. (2008b). La nulidad y la rescisión en el derecho civil chileno 3a ed., Vol. 2). Santiago: Editorial jurídica de Chile.

Atienza Rodríguez, M. y Ruiz Manero, J. (2003). Seis acotaciones preliminares para una teoría de la validez jurídica.Doxa. (Alicante, Internet), (26), 719-735. https://doi.org/10.14198/doxa2003.26.28

Bandrac, M. (1986). La nature juridique de la prescripción extinctive en matière civile. Paris: Economica.

Baraona González, J. (2008). La acción redhibitoria como acción de nulidad. En A. Guzmán Brito (Ed.), Estudios de derecho civil (Vol. 3, pp, 659-669). Santiago: LegalPublishing.

Baraona González, J. (2012) La nulidad de los actos jurídicos: consideraciones históricas y dogmáticas. Bogotá: Universidad Javeriana-Ibáñez.

B.S.A. con C.S.A, 17735-2008 (23 Juzgado Civil de Santiago, 29 de agosto de 2013). Recuperado de https://bit.ly/31NAbYC 
Campbell, D. (2005). The function and structure of remedies for failure to perform a contractual obligation. En D. Harris, D. Campbell \& R. Haldon. Remedies in contract \& tort. (2a ed., pp. 3-24). Cambridge: Cambridge University press.

Caprile Biermann, B. (2008). Las acciones del comprador insatisfecho: el cúmulo actual (Ley de protección al consumidor, vicios redhibitorios, error sustancial, resolución por incumplimiento) y la tendencia al deber de conformidad en el derecho comparado. En F. Mantilla Espinosa, C. Pizarro Wilson (Coords.), Estudios de derecho privado en homenaje al profesor Christian Larroumet (pp. 57-601). Santiago: Fundación Fernando Fueyo.

Chantepie, G. y Latina, M. (2016). La réforme du droit des obligations. Commentaire théorique et practique dans I' ordre du code civil. Paris: Dalloz.

Chile, Ministerio de Justicia. (2015). Código civil. Recuperado de http://bcn.cl/1uu74

Claro Solar, L. (1939). De las obligaciones (Vol. 3). Santiago: Nascimento.

Concha Machuca, R. (2010). El objeto ilícito contrario al derecho público (artículo 1462 del Código Civil). En Departamento de derecho privado Universidad de Concepción (Coord.), Estudios de derecho civil (Vol. 5, pp. 70-90). Santiago: Thomson Reuters.

Concha Machuca, R. (2015). Nulidad e invalidez en el código civil de Bello, en especial en cuanto a su forma de operar. Revista de derecho Uninorte, (44), 31-49. https://doi.org/10.14482/dere.44.7168

Concha Machuca, R. (2016). El juez puede declarar de oficio la nulidad absoluta aún transcurridos diez años desde la celebración del contrato. En M. Barría Paredes (Coord.), Estudios de derecho civil (Vol. 11, pp. 527-539). Santiago: Thomson Reuters.

Contardo González, J. I. (2015). Indemnización y resolución por incumplimiento. Santiago: Thomson Reuters.

Contardo González, J. I. (2015b). Obligaciones y responsabilidad civil. Revista chilena de derecho privado, (25), 203-215. https://doi.org/10.4067/s071880722015000200007

Couturier, G. (1972). La confirmation des actes nuls, Paris: L.G.D.J.

Corral Talciani, H. (2007). El ejercicio de la acción de nulidad por un tercero no contratante. En A. Guzmán Brito (Ed.), Estudios de derecho civil (Vol. 3, pp. 671-689). Santiago: LegalPublishing.

Cumyn, M. (2002). La validité du contrat suivant le droit strict ou l' équite: étude historique et comparée des nullités contractuel. Paris: L.G.D.J. 
C.T.T. con T.T.R., 1908-2008 (Corte Suprema 19 de enero 2010). Recuperado de https://bit.ly/2ADy8ur

De Castro y Bravo, F. (1985). El negocio jurídico. Madrid: Civitas.

De la Maza Gazmuri, I. (2010). Los límites del deber precontractual de información. Madrid: Civitas-Thomson Reuters.

De la Maza Gazmuri, I. (2011). El concurso entre el error con trascendencia anulatoria y el incumplimiento resolutorio. Cuadernos de análisis jurídico, (7), 213-234. Recuperado de https://bit.ly/2oM4dgP

De la Maza Gazmuri, I. (2013). La integración de la publicidad en el contrato. En C. Domínguez Hidalgo, J. González Castillo, M. Barrientos Zamorano y J. L. Goldenberg Serrano (Coord.), Estudios de derecho civil (Vol. 7, pp. 439-453). Santiago: LegalPublishing.

De La Maza Gazmuri, I. (2014). La tutela del comprador frente a la ausencia de calidades presupuestas en la cosa. Revista de derecho (Valparaíso), (43), 117-159. https://doi.org/10.4067/s0718-68512014000200003.

De la Maza Gazmuri, I. (2015). La integración publicitaria y la publicidad engañosa como supuesto de error provocado. En M. Barría Paredes, B. Caprile Biermann, J. L. Diez Schwerter, C. Domínguez Hidalgo, C. Pizarro Wilson y M. Tapia Rodríguez (Eds.), Estudios de derecho privado. Homenaje al profesor Ramón Domínguez Águila (pp. 551571). Santiago: Thomson Reuters.

De la Maza Gazmuri, I. (16 Noviembre 2015). El error en los cerdos. El Mercurio legal móvil. Recuperado de https://bit.ly/2nbpkIY

De Cossio y Corral, A. (1977). Instituciones de derecho civil. Parte general. Derecho de obligaciones (Vol. 1). Madrid: Alianza.

Delgado Echeverría, J. (2007). ¿Sanción de invalidez?: los conceptos de invalidez y sanción. En su Las nulidades de los contratos: un sistema en evolución (pp. 89-138). Navarra: Aranzadi.

Demolombe, C. (1860). Traité du mariage et de la séparation du corps (12a ed., Vol. 1). Paris: Imprimerie Génerale.

Demolombe, C. (1876). Traité des contrats et les obligations conventionnelles en générale(Vol. 6). Paris: Imprimerie Génerale. 
Deshayes, O., Genicon, T. y Laithier, Y. M. (2016). Reforme du droit des contracts, du régimen générale et de la prevue des obligations. Comentaire article par article. Paris: Lexis Nexis.

Díez-Picazo, L. (2007). Fundamentos del derecho civil patrimonial: introducción a la teoría del contrato (6a ed., Vol 1). Navarra: Civitas.

Díez-Picazo, L. y Gullón Ballesteros, A. (2015). Sistema de derecho civil. Contratos en especial. Cuasi contratos. Enriquecimiento sin causa. Responsabilidad extracontractual (11a ed., Vol. 2). Madrid: Tecnos.

Domínguez Águila, R. (2012). Teoría general del negocio jurídico (2a ed.). Santiago: Editorial Jurídica de Chile.

Ducci Claro, C. (1988). Derecho civil: parte general (3a ed.). Santiago: Editorial Jurídica de Chile.

Drogoul, F. (1902). Essai d' une theorie genérale des nullités. Étude de droit civil. Paris: A. Rosseau.

Elorriaga De Bonis, F. (2009). Las dos hipótesis de objeto ilícito contenidas en el artículo 1465 del código civil. Revista chilena de derecho privado, (12). https://doi.org/10.4067/s0718-80722009000100004.

Elgueta Anguita, A. (1981). Resolución de contratos y excepción de pago. Santiago: Editorial Jurídica.

Fabres, J. C. (1908). De la nulidad y la rescisión. En Obras Completas (Vol. 3). Santiago. Imprenta Cervantes.

Fenoy Picón, N. (2017). La revisión del tratamiento de la imposibilidad inicial y del error en los contratos, a través del análisis jurídico de diversos textos jurídicos. Anuario de derecho civil, 70(2), 473-785. Recuperado de https://bit.ly/32YEDE0

France. (2007). Code civil. Recuperado de http://bit.ly/2km2M6W

Fueyo Laneri, F. (2004). Cumplimiento e incumplimiento de las obligaciones. (3a ed). Santiago: Editorial jurídica de Chile.

García Rubio, M. P. y Otero Crespo, M. (2010). La responsabilidad precontractual en el derecho contractual europeo. Indret, 10(2), 1-62. Recuperado de https://bit.ly/2cz4FaU

G.I.L. con C.I.D.S.S.A., 1287-2008 (Corte Suprema 19 de enero de 2008). Recuperado de https://bit.ly/2og2BMj 
Ginés Castellet, N. (2016). La ventaja o explotación injusta en el ¿futuro? Derecho contractual. Indret, 16(4), 1-58. Recuperado de https://bit.ly/30KeCae

Giorgi, J. (1913). Teoría de las obligaciones en el derecho moderno (Vol. 8). Madrid: Hijos de Reus editores.

Guinchard, S., \& Debard, T. (Eds.). (2016). Lexique des termes juridiques (24a ed.). Paris: Dalloz.

Guzmán Brito, A. (2007). Sobre la relación entre las acciones de saneamiento de los vicios redhibitorios y las acciones comunes de indemnización, con especial referencia a su prescripción. Revista chilena de derecho privado, (9), 95-119. Recuperado de https://bit.ly/2OiyjTO

Ghestin, J. (1980). Droit civil. Les obligations. Le contract (Vol. 2). Paris: L.G.D.J.

Hart, H. L. A. (1977). El concepto de derecho. (G. R. Carrio, Trad.). Buenos Aires: Abeledo-Perrot.

Irti, N.(1987). La nulità como sanzione civile. Contratto e impresa, 3(2), 541-550.

Japiot, R. (1909). Des nullités en matière d' actes juridiques. Essai d' une théorie nouvelle. (thèse pour le doctorat). Université de Dijon, Dijon, France.

Jerez Delgado, C. (2011). La anulación del contrato. Navarra: Civitas.

Larroucau Torres, J. (2015). Vicios, acciones y prueba en la compraventa. Revista de derecho (Coquimbo. En línea), 22(1), 259-306. https://doi.org/10.4067/s071897532015000100007

Lando, O. y Beale, H. (2003). Principios de derecho contractual europeo. (P. Barres Benlloch, J. Embid Irujo y F. Martínez Sanz, Trads.). Madrid: Colegios notariales de España.

La Pradelle, G. (1967). Les conflicts de lois en matière de nullités (du droit interne français au droit international privé). Paris: Dalloz.

Lichbacher, R. (2007). Cass. com., 23 oct. 2007, no 06-13979. Defrénois (En Ligne), (24), 1729-1733. Recuperado de https://bit.ly/2oJH9PP

López Díaz, P. V. (2015). La autonomía de la indemnización de daños por incumplimiento de un contrato bilateral en el código civil chileno. Santiago: Editorial Thomson Reuters.

López Díaz, P. V. (2016). La indemnización de daños por vicios redhibitorios como medio de tutela precontractual autónomo en el código civil chileno: un tópico cuya procedencia y alcance aún permanecen difusos. En M. Barría Paredes (Coord.), Estudios de derecho civil (Vol. 11, pp. 689-683). Santiago: Thomson Reuters. 
López Díaz, P. V. (2017). La naturaleza jurídica de la acción redhibitoria en el código civil chileno: ¿nulidad relativa, resolución por incumplimiento o rescisión propiamente tal? Revista chilena de derecho, 44(2), 423-459. https://doi.org/10.4067/S071834372017000200423

López Díaz, P. V. (2017b). La noción de lesión enorme en el código civil chileno: una manifestación del equilibrio contractual orientada prevalentemente a configurar la adaptación del contrato como medio de tutela precontractual. En J. Contardo González e I. De la Maza Gazmuri (Dirs.), La compraventa. Estudios (pp. 658-708). Santiago: Thomson Reuters.

López Díaz, P. V. (2017c). Por la articulación de un sistema de medios de tutela precontractual en el código civil chileno. En H. Corral Talciani y P. Manterola González (Eds.), Estudios de derecho civil (Vol. 12, pp. 465-483). Santiago: Thomson Reuters.

López Díaz, P. V. (2017d). La tutela precontractual y contractual del acreedor en el código civil chileno: dos sistemas estructuralmente diversos, pero, ¿plenamente coherentes y convergentes? Revista chilena de derecho privado, (29), 9-98. https://doi.org/10.4067/s0718-80722017000200009

López Díaz, P. V. (2018). La adaptación del contrato como medio de tutela precontractual en el código civil chileno. Revista de derecho (Valdivia), 31(1), 127-157. https://doi.org/10.4067/s0718-09502018000100127

López Díaz, P. V. (2018b). Tutela precontractual versus tutela contractual en el código civil chileno: ¿efecto espejo o reflejo?. En C. Bahamondes Oyarzún, L. Etcheberry Court y Carlos Pizarro Wilson (Eds.), Estudios de derecho civil (Vol. 13, pp. 707-736). Santiago: Thomson Reuters.

Martín Pérez, J. A. (1995). La rescisión del contrato (en torno a la lesión contractual y el fraude de acreedores). Barcelona: Bosh.

Martinic Galetovic, D. y Reveco Urzúa, R. (2005). Acerca del error, su excusabilidad y otros tópicos. En J. Varas Braun, Juan y S. Turner Saelzer (Coords.), Estudios de derecho civil. (pp. 259-296). Santiago: Lexis Nexis.

Mejías Alonzo, C. (2011). El incumplimiento resolutorio en el código civil. Santiago: AbeledoPerrot.

Mejías Alonzo, C. (2016). Una revisión crítica de los efectos de la resolución por incumplimiento y una propuesta de solución. lus et praxis, 22(1), 271-322. https://doi.org/10.4067/s0718-00122016000100009

Mekki, M. (2017). Fiche practique: la nullité, entre tradition et modernité. Gazette du palais, 137(1), 115-117. Recuperado de https://bit.ly/2ofAugr 
Morales Moreno, A. M. (2006). Evolución del concepto de obligación en derecho español. En su La modernización del derecho de obligaciones (pp.17-54). Navarra: Thomson Civitas.

Morales Moreno, A. M. (2011). ¿Es posible construir un sistema precontractual de remedios? reflexiones sobre la propuesta de modernización del derecho de obligaciones y contratos en el marco del derecho europeo. En K. Albiez (Dir.), M. L. Palazón y M. Méndez (Coords.), Derecho privado europeo y modernización del derecho contractual en España (pp. 400-422). Barcelona: Atelier.

Palazón Garrido, M. L. (2014). Los remedios frente al incumplimiento en el derecho comparado. Navarra: Aranzadi Thomson Reuters.

Pescio, V. (1958). Manual de derecho civil. Teoría general de los actos jurídicos y teoría general de la prueba (Vol. 2). Santiago: Editorial Jurídica de Chile.

Pizarro Wilson, C. (2012). Contra el efecto retroactivo de la resolución por incumplimiento contractual. En F. Elorriaga (Coord.), Estudios de derecho civil (Vol. 7, pp. 449460). Santiago: Thomson Reuters.

Pizarro Wilson, C. (2007). ¿Puede el acreedor poner término unilateral al contrato?. lus et praxis, 13(1), 11-28. https://doi.org/10.4067/s0718-00122007000100002

Posez, A. (2011). La théorie des nullités: Le centenaire d' une mystification. RDT Civ. (4), 647-675.

Prado López, P. (2016). El dolo causal: Su repercusión en el contrato. lus et praxis, 22(2), 425-456. https://doi.org/10.4067/s0718-00122016000200014

Ríos Labbé, S. (2016). Nulidad por objeto o causa ilícita y restituciones. Otra vez sobre el artículo 1468 del código civil. En Departamento de Derecho Privado Universidad de Concepción (Ed.), M. Barría Paredes (Coord.), Estudios de derecho civil (Vol. 11). Santiago: Thomson Reuters.

Rodríguez Grez, P. (1995). Inexistencia y nulidad en el Código Civil. Teoría bimembre de la nulidad. Santiago: Editorial Jurídica de Chile.

Rossel Saavedra, E. (1926). Teoría de las nulidades. Santiago: Balcells.

Roubier, P. (2005) Drois subjectifs et situations jurídiques. Paris: Dalloz.

San Martín Neira, L. C. (2015). La Teoría de la inexistencia y su falta de cabida en el código civil chileno. Revista chilena de derecho,42(3), 745-784. https://doi.org/10.4067/s0718-34372015000300002

Santaella López, M. (2003). Derecho de la publicidad. Madrid: Civitas. 
S.A.S.A. con F. M.S.A., 3657-2015 (Corte Suprema 7 de octubre de 2017). Recuperado de https://bit.ly/2Mh0aRG

Severin Fuster, G. (2017). La nulidad absoluta en los principios latinoamericanos de derecho de los contratos. Sobre su inclusión en el texto y sus causales. Anuario de derecho civil, 70(4), 1483-1542. Recuperado de http://bit.ly/32ZV6I5

Starck, B. (1986). Droit Civil: obligations. Contrat et quasi-contrat, régime générale. (2a ed., Vol. 2). Paris: Librairies Techniques.

Thibierge, C. (2010). Nulidad, restituciones y responsabilidad. (G. de Greiff, Trad.). Bogotá: Universidad Externado de Colombia.

Ugarte Godoy, J. J. (2016). La inexistencia jurídica. En Departamento de Derecho Privado Universidad de Concepción (Ed.), M. Barría Paredes (Coord.), Estudios de derecho civil (Vol. 11, pp. 815-840). Santiago: Thomson Reuters.

Instituto Internacional para la Unificación del Derecho Privado. (2010). Principios Unidroit sobre los contratos comerciales internacionales, 2010 (3a ed.). Madrid: La Ley. Recuperado de http://bit.ly/355cDRb

Vial del Río, V. (2003). Teoría general del acto jurídico (5a ed.), Santiago: Editorial Jurídica de Chile.

Vidal Olivares, Á. (2007). Cumplimiento e incumplimiento contractual en el código civil: una perspectiva más realista. Revista chilena de derecho, 34(1), 41-59. https://doi.org/10.4067/s0718-34372007000100004

Vidal Olivares, Á. (2009). La noción de incumplimiento esencial en el "código civil". Revista de derecho (Valparaíso), (32), 221-258. https://doi.org/10.4067/s071868512009000100006

Vío Vásquez, E. (1945). Las obligaciones condicionales. Doctrina - jurisprudencia - legislación comparada. Concepción: Escuela Tipográfica Salesiana.

Voirin, P.y Gobeaux, G. (2011). Droit Civil. (33a ed., Vol. 1) Paris: L.G.D.J.

\section{Para citar este artículo bajo Norma APA 6a ed. \\ López Díaz, P. V. (2019). La nulidad como un medio de tutela precontractual en el Código Civil chileno. Revista de Derecho (Coquimbo. En línea), 26, e3597, http://doi.org/10.22199/issn.0718-9753-2019-0005}

Copyright del articulo: @2019 Patricia López

Este es un artículo de acceso abierto, bajo licencia Creative Commons BY 4.0. 